\title{
Yargıya yansıyan Ortopedi ve Travmatoloji vakaları
}

\author{
Orthopaedics and traumatology cases subject to jurisdiction
}

\author{
Serdar Şirazi \\ Ortopedi ve Travmatoloji Uzmanı - Hukukçu, Özel İstanbul Şafak Hastanesi - Şahin Avukatlık Bürosu, İstanbul
}

\begin{abstract}
Sağlık hizmetlerinin ana sunucularından olan hekimler ile hastalar arasında son dönemlerde artan sayıda davalar olmaktadır. Ortopedi ve Travmatoloji uzmanlarının sağlık hizmetinde önemli bir yere sahip olması nedeniyle, yazımızda yargıya yansıyan davaların bir kısmına yer verdik. Bu çalışma, Ortopedi ve Travmatoloji uzmanlarının hukuki olarak ne tür problemlerle karşı karşıya kalabilecekleri konusunda fikir sahibi olunması yönünde katkı sağlayacaktır.
\end{abstract}

Anahtar sözcülkler: ortopedi ve travmatoloji; sağlık hukuku; malpraktis
There has been an increase in number of legal cases between patients, and physicians as the main providers of healthcare services. Since orthopedics and traumatology specialists have an important place in healthcare, we have included some of the cases reflected in the judiciary in our article. This study will contribute to the understanding of the legal problems that orthopedics and traumatology specialists may encounter.

Key words: orthopaedics and traumatology; health law; malpractice

söz konusu çalışmamız yüksek mahkeme kararlarını inceleyerek bu kararların da sadece bir kısmını içermektedir. Büyük bir kısmı Ortopedi ve Travmatoloji hekimlerinin lehine sonuçlanan mahkeme kararlarına yer kısıtlılığından dolayı tam olarak yer verilememekle birlikte fikir sahibi olmaları için aleyhe de sonuçlanan hatta eksik inceleme sonucu bozulan kararların da bir kısmı yazımızda yer almıştır.

Yüksek mahkemeler sınıfında olan Askeri Yargıtay ve Askeri Yüksek İdare Mahkemesi OHAL(Olağanüstü Hal) kapsamında çıkarılan 694 sayılı kanun hükmünde kararname ile kapatıldı. 1219 sayılı Tababet ve Şuabatı Sanatlarının Tarzı İcrasına Dair Kanunun 75. maddesi hükmü gereğince tıbbi müdahalelerden kaynaklanan uyuşmazlıklarla ilgili olarak resmi bilirkişi olarak belirlenen ve özellikle ceza davaları açısından bilirkişiliğine başvurulan Yüksek Sağlık Şurası'ndan rapor alma zorunluluğunu öngören madde Anayasa Mahkemesi'nin 03.06.2010 tarih E. 2009/69, K. 2010/79 sayılı kararı ile iptal edildi. Karar 22.10.2010 tarihinde Resmi Gazetede yayınlandı.

Her ne kadar kaldırılmış olsa da Askeri Yüksek İdare Mahkemesi'nin vermiş olduğu karara yer vermek doğru olacaktır kanaatindeyim.

- İletişim adresi: Dr. Serdar Şirazi, Özel İstanbul Şafak Hastanesi, Hürriyet Mah. Eski Edirne Asf. No:124/B, 500 Evler, Gaziosmanpaşa, İstanbul Tel: 0536 - 6811187 e-posta: drserdarsirazi@yahoo.com

- Geliș tarihi: 18 Kasım 2019 Kabul tarihi: 17 Aralık 2019 
Askeri Yüksek idare Mahkemesi 2. Daire'sinin 01.12.2004 tarihli E: 2002/959, K: 2004/905 sayılı kararında müteveffa çavuşun askerlik hizmetini yaparken 15 Nisan 2000 günü sabah sporunda uzun atlama esnasında düştüğü ve $L 3$ vertebra kemiğinin kırıldığı, aynı gün sevk edildiği ... Asker Hastanesi acil polikliniğinde doktor tarafindan muayene edildikten sonra sevk kâğıdına Baştabipliğe, mekanik bel ağrısı, müşahede edildi, tedavi düzenlendiği, 3 gün istirahat verildiği, beyin cerrahi servisine kontrole gelecek yazılarak birliğine geri gönderildiği, müteveffanın... Asker Hastanesi Nöroşirürji polikliniğine sevk edildiği, çekilen MR filmi ile birlikte tekrar Mareşal Fevzi Çakmak Asker Hastanesi Beyin Cerrahi polikliniğine gelen müteveffanın, yatarak tedavi uygulandığı, Sağlık Kurulunun raporu ile L3 kompresyon kırığı, hastanın THY (Türk Hava Yolları) uçağı ile yatarak hemşire refakatinde sevk edildiği... Ortopedi Kliniğinde alçı korse uygulandığı, hava değişiminde iken... Tıp Fakültesinde iki kez ameliyat uygulandığı, 08 Şubat 2001 tarihinde ... başvurusu üzerine Ewing sarkomu teşhisi konarak kemoterapiye başlandığı, daha sonra kompresyon fraktürü nedeni ile operasyon uygulandığı, operasyondan sonra progresyon saptanması üzerine yeni tedavi rejimi düzenlendiği ve son kemoterapinin uygulanmasından sonra hava değişimindeyken vefat ettiği, davacı vekilinin müvekkillerinin ölüm olayının görev sırasında meydana gelen sakatlanmadan kaynaklandığı, spor yapılan yerin idare tarafından temizlenmediği için düşme ve L3. vertebra kırığının meydana geldiği, kırığın tedavisinin yeterli yapılmadığı, ilk müdahalede yanlış teşhis konduğu, hatta kırığın dahi tespit edilmediği, tıbbi tedavide gerekli özenin gösterilmediği, idarenin yeterli tedavi yapmayarak hizmet kusuru işlediği iddiasında bulunmuştur. Ewing sarkom tedavisinde tıbben ihmal ya da hata bulunup bulunmadığı, meydana gelen ölüm olayının yapılan tüm tedavilerdeki ihmal ve gecikmelerden kaynaklanıp kaynaklanmadığı uzmanlardan oluşan bilirkişiden sorularak aydınlatılmıştır. Bilirkişi raporunda; sonuç olarak, düşme sonucu meydana gelen vertebra kırığı ile 8 ay kadar sonra ortaya çıkan Ewing sarkomu arasında bir ilişkinin olmadığı, Ewing sarkom hastalığının tedavisinde herhangi bir ihmal veya hatanın söz konusu olmadığı, Ewing sarkomun erişkin yaş gurubunda prognozu kötü olan bir hastalık olduğu ve hastaların büyük oranda bu hastalık nedeni ile kaybedildiği, çavuşun hastalığının tanı ve tedavisinde herhangi bir ihmal veya hatanın olmadığı yapılan tedavinin yeterli ve uygun olduğu bildirilmiştir. Davacı taraf bilirkişi raporuna itiraz etmiş ancak aynı bilirkişi raporu tekrar mahkemeye sunulmuştur. Söz konusu davada davacının yakınının ölümünün idarenin kusurlu bir davranışından kaynaklanmadığı bilirkişi raporu ile kanıtlandığından davalı idarenin zararlardan sorumlu olamayacağı sonuç ve kanaatine varılarak davacıların maddi ve manevi tazminat istemlerinin reddine karar vermiştir.

Anayasa Mahkemesine bireysel başvuru sonucunda 15.03.2018 tarihli E: 2014/19349 K. 2018/Genel Kurul kararında başvurucunun yakınının bir hastaneden başka bir hastaneye yapılması planlanan sevk işleminin kabul edilmemesi sonrasında ölüm olayının meydana gelmesi ve bu olay ile ilgili olarak başlatılan ceza soruşturmasının etkili bir şekilde yürütülmemesi nedenleriyle yaşam hakkının ihlal edildiği iddiasına ilişkin davada davacının yakınının motosiklet kazası sonucu 112 acil ambulansıyla multitravma tanısıyla bilinci açık bir şekilde... Devlet Hastanesi Acil Polikliniğine götürüldüğü, yapılan tetkikler neticesinde kırıklar tespit edildiği ve genel cerrahi uzmanından, beyin ve sinir cerrahisinden ve ortopedi uzmanından konsültasyon istendiği, genel cerrahi ve beyin ve sinir cerrahisi konsültasyonunda, hastanın sağlık durumunda acil cerrahi müdahale gerektirecek patolojik bir durum saptanmadığı ortopedi konsültasyonunda ise hastanın sağlık durumunun yoğun bakım şartlarını gerektirdiği, ileri tetkik ve tedavi için hastanın başka bir hastaneye sevk edilmesi gerektiği değerlendirilmiştir. Hastanın sağlık durumunun yoğun bakım şartlarını gerektirdiğinin anlaşılması üzerine ... Devlet Hastanesi yetkililerince ... Hastanesi Ortopedi servisindeki nöbetçi doktorlarla görüşülmüştür. Yapılan görüşmelerde ... Hastanesinin yoğun bakım ünitelerinde boş yer olmadığı belirtilmiştir. Bunun üzerine hasta ... Tıp Fakültesi Hastanesine sevk edilmiş, bilinci bulanık şekilde giriş yapan hastanın, saat 00:25'te arrest olması üzerine 02:25'te öldüğü kabul edilmiş. Ceza soruşturmasında... Cumhuriyet Başsavcılığı, ... Üniversitesi Hastanesinin olayla ilgili personeli hakkında Yüksek Öğretim Kanunu uyarınca görevsizlik kararı vermiş ve bu kişiler hakkındaki soruşturma dosyasını ... Üniversitesi Rektörlüğüne göndermiştir. ... Cumhuriyet Başsavcılığının anılan kararı üzerine ... Üniversitesi Hastanesinin olayla ilgili personeli hakkında Üniversite Rektörlüğü tarafından soruşturma başlatılmıştır. Bu kapsamda soruşturmacı doktorların cezai sorumluluğunu gerektirecek herhangi bir fiilinin bulunmadığı yönünde kanaat bildiren bir rapor hazırlanmıştır. ... Üniversitesi Rektörlüğü, anılan soruşturma dosyasını dikkate alarak sevki kabul etmeyen doktorların kusurunun bulunmadığı kanaatine varmış ve 21.10.2008 tarihli kararla men-i muhakeme kararı vermiştir. Başvurucunun bu karara itiraz etmesi üzerine Danıştay Birinci Dairesi 16.01.2009 tarihli ilam ile men-i muhakeme kararının bozulmasına karar vermiş, gerekçe olarak da yoğun bakım ünitesinde boşyer olmaması 
gösterilmiş ise de yoğun bakım ünitesine ek yatak konulması, başka servislerden yatak ayarlanması veya kısa bir süre için dahi olsa yoğun bakım ünitesinden çıkarılabilecek hastalarla yer değiştirilmesi gibi alternatif çözümlerin aranmadığı, hastanenin fiziki şartları da dahil olmak üzere hastanın hastaneye kabul edilmemesi için hiçbir mazeret ileri sürülemeyeceği belirtilmiştir. Bunun üzerine Cumhuriyet Başsavcılığınca doktorlar hakkında iddianame düzenlenerek 3. Asliye Ceza Mahkemesinde kamu davası açılmıştır. Mahkeme, yaşanan olayla ilgili olarak Yüksek Sağlık Şurasından bilirkişi raporu almıştır. Yüksek Sağlık Şurası'ndan alınan raporun sonuç kısmı şöyledir: "Dosyadaki bilgi, belge ve bulgular değerlendirildiğinde; hastanın ilk müracaat ettiği hastanede değerlendirilmesi sırasında gerekli olduğu halde akciğer grafisinin çekilmediğinin (dosyada mevcut olmadığının) anlaşıldığı, hastanın toraks incelemesinin yeterli düzeyde yapılmadığı, bunun bir kusur olduğu, diğer branş konsültasyonlarının uygun olarak yapıldığı ve yaralanmanın ciddiyeti nedeniyle yoğun bakım ünitesinde bakımının zorunlu olduğu, yoğun bakımda yer olmaması nedeniyle hastayı kabul etmeyen doktorların eylemlerinde kusurlu olmadıklarına, hastanın sevk edildiği... Üniversitesi Hastanesinde yapılan işlemlerin tıp kurallarına uygun olduğuna, şuramızca oy birliği ile karar verildi." ... 3. Asliye Ceza Mahkemesi, gerek tarafların beyanlarını gerekse hasta hakkındaki tıbbi belgeler ile raporları dikkate alarak sevki kabul etmeyen doktorlar hakkında beraatına karar vermiştir. Temyiz talebini inceleyen Yargıtay 12. Ceza Dairesi ilk derece mahkemesi kararının onanmasına karar vermiş ve başvurucu bireysel başvuruda bulunmuştur. Adli Tıp Kurumu Birinci ihtisas Kurulundan, akabinde ise Adli Tıp Kurumu Genel Kurulundan bilirkişi raporu düzenlenmesini istemiştir. Her iki raporda da davalı hastanenin hastayı kabul etmemesinde kusurunun bulunmadığı yönünde görüş bildirilmiştir. ... 2. İdare Mahkemesi 26.06.2015 tarihli kararla her ne kadar Adli Tıp Kurumu Genel Kurulu tarafindan, hastayı kabul etmemesiyle ilgili olarak hastanenin kusurlu olmadığı yönünde görüş beyan edilmiş ise de hastaneler arasındaki koordinasyonsuzluk ve yoğun bakımda yer olmadığı gerekçesiyle hastanın kabul edilmemesi ve o gün nöbetçi olan doktorun hastanede bulunmayarak asistanı yönlendirmeye çalışması, davalı idarenin üzerine düşen yükümlülüğü yerine getirmediğini gösterdiğinden tazminat sorumluluğunun koşullarının oluştuğu sonucuna varmıştır. Mahkeme, maddi tazminatın başvurucu ve eşine müştereken ödenmesine karar vermiştir. Taraflarca temyiz edilen karar, Danıştay Onbeşinci Dairesinin 21.04.2016 tarihli ilamı ile dava konusu olayda ... Üniversitesi Hastanesinin tespit edilmiş herhangi bir kusurlu tıbbi uygulamasının bulunmadığı gerekçesiyle bozulmuştur. Başvurucunun karar düzeltme talebi, aynı dairenin 13.12.2016 tarihli ilamı ile reddedilmiştir. Başvuru konusu olay ağır kişisel kusur veya kasıttan ziyade sadece idarenin işleyişindeki veya düzenlenmesindeki nesnel bir hatadan, aksaklıktan veya öngörüsüzlükten kaynaklanmışsa tazminat yolunun yeterli olabileceği ve bu yolun ölen kişinin yakınlarının mağduriyetini ortadan kaldırabileceği düşünülebilir. Bu durumda başvurucunun bu yolu tüketmesi ondan beklenebilir. Bununla birlikte önümüzdeki olay Anayasa Mahkemesinin başvuru yolları tüketilmediği gerekçesiyle kabul edilemezlik kararları verdiği tıbbi hataya ilişkin diğer başvurulardan farklılık göstermektedir. Anayasa Mahkemesine göre yaşam hakkının veya vücut bütünlüğünün ihlaline kasten sebebiyet verilmediği durumlarda tüketilmesi gereken uygun hukuki çare tazminat yoludur. Dolayısıyla Anayasa Mahkemesi yaşam hakkının ihlal edildiğine ilişkin iddianın başvuru yollarının tüketilmemesi nedeniyle kabul edilemez olduğuna oy çokluğuyla karar vermiştir.

Ankara Bölge Adliye Mahkemesinin aydınlatılmış onam ile ilgili bir kararında;

Mahkemece; davanın doktor hatasına dayalı maddi ve manevi tazminat istemine ilişkin olduğu, davacının ameliyatını servikal disk hernisi nedeniyle davalı doktor ve ekibi tarafından yapılmış ise de anılan doktorun ameliyatı davalı şirkete ait hastanede yaptığı, hastanenin ameliyathane, muayene odası gibi mekânlarını ve imkânlarını kullandığı, davalı hastanenin doktor ile birlikte hastalara karşı müteselsil sorumlu olduğunun kabulünün gerektiği, davalılar arasında hastaların ve üçüncü kişilerin uğrayacağı zarardan doktorun sorumlu olacağı yönünde hüküm mevcut ise de, bunun davalılar arasındaki iç ilişki ile ilgili olduğu ve davacı tarafı bağlamayacağı, davanın vekâlet sözleşmesinden kaynaklandığı ve BK'nun 126/4. (TBK'nun 147/5.) maddesi uyarınca 5 yıllık zamanaşımına tabi olduğu ve ameliyat tarihinden dava tarihine kadar öngörülen zamanaşımı süresinin dolmadığı, her ne kadar davacının Cumhuriyet Başsavcılığı'na doktorunun suçsuz olduğunu, bu nedenle şikâyetinden vazgeçtiğini ve ayrıca yine İlgili Makama" başlıklı belgede özetle, doktor hakkındaki şikâyetimden vazgeçiyorum, şahsi hakkım olan maddi ve manevi tazminat taleplerimden gayri kabil-i rücu feragat ediyorum" şeklinde beyanda bulunmuş ise de davacının ilk ameliyattan sonra boynundan aşağı felç kaldığı ve davalı doktor ile ilişkilerinin sürdüğü ve daha sonra davacının aynı hastaneye yatarak davalı doktor tarafından kök hücre ameliyatı yapıldığı anlaşıldığından bu feragatnamenin davacının özgür iradesi ile verilmediği, davacının bunu manevi baskı altında verdiği benimsenerek yapılan yargılama neticesinde; toplanan tüm kanıtlar ve birbiri ile uyum halinde olan 
bilirkişi raporlarına göre, davaya konu boyun fitığı ameliyatının yapılması ve sonrasında doktora izafe edilebilecek bir kusur ve özen eksikliği bulunduğunun kanıtlanamadığı..." kanaatiyle davanın reddine karar verilmiştir. 1. derece mahkemenin vermiş olduğu bu karar sonrasında davacı vekili tarafından istinafa gidilmiş Bölge Adliye Mahkemesi davayı inceleyerek "Somut olayda davalılar arasında doktorlarının davalı şirketin faaliyet gösteren hastanelerinde ameliyatın davalı doktor tarafından gerçekleştirildiği ve davacının ameliyat sonrası felç kaldığı sabit olup dava konusu olaya ilişkin olarak dosyada mevcut tıbbi belge ve raporlara göre; evrak arasında mevcut olan ... Hastanesinin davacı doktor adına kayıtlı dosyasında; davacı doktor adına düzenlenen hasta yatış formunda tarih olmadığı, ön tanı olarak servikal disk hernisi yazıldığı, yatışı yapacak doktorun ve yatıran doktorun farklı kişiler olduğu, söz konusu formun "HASTA ONAYI" kısmında yazılı olan "Ben ... ... ... (bosluk) ... ... ... ... ... Hastanesi doktorlarının ve çalışma ekibinin uygulayacağı tedaviyi bilincim yerinde olarak kabul ediyorum. Hastalığımın teşhis ve tedavisi için gerekli olan ilaçların, tetkik ve girişimlerin tümünün tatbikine izin veriyorum. Cerrahi girişimlerin uygulanmasını gerektiren sebepler bana açıklanmıştır. Riskler ve komplikasyonlar anlatılmıştır. Olumsuz gelişmelerden de haberdar olarak tedavimin ... . Hastanesi'nde yapılmasını onaylıyorum." sözlerinin hemen altındaki hastanın imzası ve tarih kısımlarının doldurulmamış olduğu, hasta yakını kısmında ise arkadaşı olarak ... . adlı kişinin adres ve iletişim bilgileriyle altında imza bulunduğu görülmüştür. Adli Tıp 3. İhtisas Kurulu raporunda; davacıya uygulanan diskektomi operasyonlarında oluşan tablonun manüplasyonlar (posterior osteofit rezeksiyonu ve diskin çıkarılması) sırasında oluşabileceği gibi cage takoza bağlı olarak veya greftin medullaya basısı ile de oluşabilece$\breve{g} \mathrm{i}$, komplikasyon olarak kabul edildiği, doktorun tanı ve tedavisinin tıp kurallarına uygun olduğu oy birliği ile mütalaa edilmiştir. Adli Tıp Genel Kurulu'ndan alınan raporda; bunun bir komplikasyon olarak kabul edildiği, durum fark edilip hastanın 2. ameliyata alındığı, kişinin plejik hale geldiği, bunu gidermek için kök hücre uygulamasının ...tarihinde yapıldığı... hastada yapılan kök hücre tedavisi ile hastaya yarar sağlanamadığı..." oy birliği ile karar verilmiş. Mahkemece farklı hastanelerden konusunda uzman bilirkişilerden alınan raporda da komplikasyon olduğu..." yönünde görüş bildirilmiştir. Yapılan tedavinin başarı ile sonuçlanmaması ve hatta çok ağır bir araz ile son bulması yanlış tedavi veya kusur yerine tedavi sonrası gelişmiş olası komplikasyon olarak değerlendirilebileceği yönünde..." görüş bildirilmiştir. İtirazlar üzerine mahkemece aynı bilirkişilerden alınan ek raporda; “... hasta dosyasında aydınlatılmış onam formunun da yer aldığı, hastanın ameliyat öncesinde aydınlatılması görevinin gereği gibi yerine getirildiği, ameliyatta doktor hatası, kusuru, gerek ameliyat esnasında, gerek ameliyat sonrasında özen eksikliği bulunmadığı... hastanın tıp biliminin kurallarına uygun olarak bilgilendirildiği, olası risk ve komplikasyonların anlatıldığı, operasyon sonrasında carbon-cage' in kaymasının ve gelişen nörolojik tablonun komplikasyon olarak değerlendirildiği ve doktorun tanı ve tedavisinin tıp kurallarına uygun olduğu yönünde..." görüş bildirilmiştir. Somut olayda mahkemece, ortaya çıkan sonucun bir komplikasyon olduğunu, ameliyat sırasında ve sonrasında yapılan tedavinin tıbba ve fenne uygun olduğunu, davalı doktorun uygulamalarının tıp kurallarına uygun bulunduğunu belirten raporlara dayanılarak; “... davaya konu boyun fitığı ameliyatının yapılması ve sonrasında doktora izafe edilebilecek bir kusur ve özen eksikliği bulunduğunun kanıtlanamadığı..." kanaatiyle davanın reddine karar verilmiştir. Ancak, bilirkişi raporlarına göre ameliyat sırasında konulan implantın kayarak omuriliğe basmasının komplikasyon niteliğinde olduğu anlaşılmakta ise de yukarıda anlatılan bilgiler ışığında, davalıların komplikasyon nedeniyle sorumlu olmadığının kabulü için hastanın bu komplikasyon sonrası yaşadığı süreç ile ilgili ayrıntılı bir şekilde bilgilendirilmiş olması gerekmektedir. Mevcut durumda onam formu olarak dosyaya ibraz edilen tarihsiz hasta yatış/onay formunda hastanın, ilgili doktorun tüm cerrahi ve tıbbi işlemlerine müsaade ettiği ve davalı şirketin hastanesinde tedaviye onay verdiği yazılıdır. Her ne kadar risklerin ve komplikasyonların anlatıldığı ibaresi var ise de bahsedilen bu form davacıya yapılan ameliyatın niteliği, karşılaşılması muhtemel riskler konusunda davacıya gerekli bilginin verildiğini gösterir nitelikte değildir. Kaldı ki söz konusu belgede hastanın imza kısmı da boş bırakılmıştır. Hastanın ameliyat sırasında ve sonrasında yaşadığı sağlık sorunları ile ilgili olarak aydınlatılmadığı anlaşımaktadır. Yapılan ameliyat konusunda davacıya yeterli bilgi verildiğini ispat yükü davalı tarafa aittir. Yazılı şekilde hatalı degerlendirme ve eksik inceleme ile davanın reddine karar verilmiş olması usule ve yasaya aykırı" değerlendirmesinde bulunularak yerel mahkemenin vermiş olduğu davanın red kararını Ankara Bölge Adliye Mahkemesi 01.03.2018 tarihli E: 2017/1404, K: 2018/334 sayılı kararıyla iptal etmiştir.

\section{* $\quad * \quad *$}

Gaziantep Bölge İdare Mahkemesi 3. İdari Dava Dairesi'nin 14.01.2019 tarihliE:2018/2060 K:2019/41 sayılı kararında davacıların yakını müteveffa'nın geçirmiş olduğu trafik kazası nedeni ile devlet hastanesine getirilerek acil hekimi tarafindan çağırılan ortopedi doktoru tarafından pelvis kırığı tanısıyla, stabilizasyonun sağlanarak taburcu edildiği, Adi Tıp Kurumu 1. 
Ihtisas Kurulunun kişinin geçirdiği trafik kazasına bağlı yaralanması ile ölümü arasında illiyet bağının olduğu, tespit edilen pelvis kırığının ağırlığı ve özellikleri dikkate alındığında, doktor tarafından taburcu edilmesinin tıp kurallarına uygun olmadığı, ancak hastanın yakınları tarafindan ... Devlet Hastanesinden taburcu edilmesi sonrası hemen ...Eğitim Araştırma Hastanesi'ne götürüldüğü, burada yapılan tetkiklerle, kişinin uygun takip ve tedavisine rağmen üç gün sonra hastanede öldüğü cihetle; kişinin ölüm olayında ...Devlet Hastanesi'nden taburcu edilmesinin etkisinin ve katkısının olduğunun tıbbi delillerinin bulunmadığı, yönünde görüş belirtilmiştir. Uyuşmazlıkta, Adli Tıp Kurumunca düzenlenen bilirkişi raporunda da belirtildiği gibi davacılar murisinde tespit edilen pelvis kırı̆ğın ağırlığı ve özellikleri dikkate alındığında, doktor tarafından tabucu edilmesinin tıp kurallarına uygun olmadığı, hastanın yakınları tarafindan ...Devlet Hastanesi'nden taburcu edilmesi sonrası kendi araçlarıyla ...Eğitim Araştırma Hastanesi'ne götürülmüş olmasının davalı idarenin hizmet kusurunu ortadan kaldırmayacağı, idari hizmetin kötü işletildiğinin açık olduğu görülmekle, ölüm olayının gerçekleşmesinde \%100 kusurlu olan idarece davacıların maddi ve manevi tazminat taleplerinin karşılanması gerektiği sonucuna varılmaktadır. Yetersiz sağlık hizmeti nedeniyle duyulan sıkıntı ve üzüntünün kısmen de olsa hafifletilebilmesi amacıyla davacılar lehine manevi tazminata hükmedilmesi gerektiği, olayın oluşumu ve niteliği dikkate alınarak takdiren toplam 165,000-TL manevi tazminatın idareye başvuru tarihinden itibaren işletilecek yasal faiziyle birlikte ödenmesine karar verilmiş. Bölge İdare Mahkemesi de davacıların manevi tazminat ödenmesi istemine ilişkin olarak, İdare Mahkemesi kararının manevi tazminata ilişkin kısmını hukuka uygun bulup, kaldırılmasını gerektiren bir neden bulunmadığından kararın bu kısmına yönelik tarafların istinaf başvurusunun reddi gerektiği sonucuna varmıştır.

$$
\text { * * * }
$$

Dava; Ankara 14. İdare Mahkemesi'nce; düşme sonucu sol humerus alt ucunda kırık meydana gelen ve başvurduğu ... Eğitim ve Araştırma Hastanesi'nde opere edilen ve sonrasında hareket kısıtlılığı ile ağrısı olan ve bu nedenle üçüncü bir kez başka bir merkezde opere edilen davacı kolundaki platinlerin çıkarılmasına ait tıbbi bilgi ve belgelerin ve buna ilişkin hasta dosyasının aslı veya onaylı örneği istenilmiş olup, davalı idarece gönderilen cevabi yazıda, bu tür ameliyatlarda kullanılan $\mathrm{K}$ tellerinin ameliyattan 3-6 hafta sonra poliklinik şartlarında çıkarılacağı, davacının da K tellerinin (3 adet) poliklinik şartlarında çekildiği, bahsedilen şikayetlerin bu tellerin çekilmesi sırasında olması beklenen bir komplikasyon olmadığı belirtilmiştir. Adli Tıp
Kurumu 3. Adli Tıp İhtisas Kurulu'nun hastaya yapılan operasyonun tıp kurallarına uygun olduğu, gelişen lezyonların bu ameliyatın bir komplikasyonu olduğu, kişinin kurulda yapılan muayenesi sonucunda, sol dirsek hareketlerinin tam olduğu ve atrofi (kas erimesi) olmadığı, 5. parmak adduksiyonu hafif kısıtlı olduğu dikkate alındığında gelişen mevcut komplikasyonların sekelsiz iyileşmiş olduğu anlaşılmakta olup idareye atfı kabil bir kusur bulunmadığı belirtilmiştir. Davacıya platin, asistan doktor ve uzman doktor eşliğinde takılmış, dosyadaki ifadelerden ise tellerin uzman doktorun önerisi ile asistan doktor tarafindan çıkarıldığı anlaşılmaktadır. K tellerinin çıkarılması uzmanlık bilgi ve deneyimi gerektiren işlerden olup olmadığı, asistan doktorun, uzman doktorun önerisi ile uzman doktor gözetimi olmadan $\mathrm{K}$ tellerini tek başına çıkarıp çıkaramayacağı hususları ile davacının rahatsızlığının teşhis ve tedavi sürecinde hizmet kusuru bulunup bulunmadığına ilişkin Adli Tıp Genel Kurulundan rapor alındıktan sonra bir karar verilmelidir. Ayrıca Adli Tıp Kurumu 3. Adli Tıp İhtisas Kurulu'nun 26.07.2013 tarih ve 2912 sayılı raporunun da özel hastanede yapılan ameliyat ve tedavilerden sonra kurulda davacının muayene edilerek tanzim edildiği göz önüne alındığında, davacıda meydana gelen durum bile, komplikasyonla mücadelede davalı idarenin üzerine düşeni yapmadığı anlaşıldığından, davacıların özel hastanede ameliyat olmak zorunda kalmaları nedeniyle yaptıkları harcamaların ve davacıların olay nedeniyle duydukları ızdırabın kısmen de olsa giderilebilmesi için manevi zararlarının tazmini gerekmektedir. (Danıştay 15. Daire 10.03.2016 tarihli E: 2014/5674, K: 2016/1586 sayılı kararı)

Danıştay 10. Daire 31.03.1997 tarihli E: 1995/7754, K: 1997/1071 sayılı kararında;

...Üniversitesi Tıp Fakültesi Ortopedi ve Travmatoloji Anabilim Dalı Başkanlığınca dava ve hastane dosyalarının incelenip, davacının da muayene edilmesinden sonra düzenlenen rapordan hastanın ayak bileği hareketlerinde hafif kısıtlılık olmasına karşın rahat yürüyebildiğini, hastanın geçirdiği trafik kazası sonucunda sağ bacağında fascia yırtığı meydana geldiğini, ... Hastanesinde yapılan fascia tamiri sonucu bu bölgenin özelliği nedeniyle akut kompartman sendromu geliştiğinin, bu olasılık göz önüne alınarak tamir sütürlerinin hemen alınması halinde komplikasyonların önlenmesinin mümkün olduğunu, yalnız sargıların alınmasının gelişmiş kompartman sendromunda yeterli olmayacağının, dolayısıyla gelişen olaylarda davalı idarenin kusurlu olduğunun, ... Hastanesinde yapılan debridman ameliyatları ve tendon transferinin başarılı olması nedeniyle bugünkü sonucun alınabildiğinin belirtildiği, bu durumda hizmeti kusurlu yürüten idarenin 
meydana gelen zararı tazmini gerektiği, ancak hafif kısıtlılığa karşın rahat yürüyebilen ve davalı idarede memur olması nedeniyle tüm tedavi giderleri karşılanan davacının maddi bir zararının bulunmadığı, meydana gelen olay ve ayak bileğindeki kısıtlılık nedeniyle atlanılan sıkıntıyı kısmen de olsa gidermek için takdir edilen 30,000,000 liranın manevi tazminat olarak davacıya ödenmesi gerektiği gerekçesiyle, 30,000,000 lira manevi tazminatın davalı idarece davacıya ödenmesine, temyiz isteminin reddine ve anılan kararın onanmasına, 31.03.1997 tarihinde oy birliği ile karar verilmiş.

Erzurum İdare Mahkemesince verilen kararda dava, davacıların yakını R. K.'ın kifoskolyoz şikâyeti nedeniyle 16.11.2005 ve sonraki tarihlerde ...hastanesinde yapılan ameliyatlar neticesinde felç kalması nedeniyle davacılardan toplam 2,460,000.-TL tazminatın yasal faizi ile birlikte ödenmesine karar verilmesi istemiyle açılmış. Söz konusu olayda, mahkemeye sunulan Adli Tıp Kurumu 3. Adli Tıp İhtisas Kurulu'nun raporunda özetle; davacıların yakınının T5-L4 arasına posterior enstrümantasyon, T10-11'e laminektomi, T9-1011 'den kama osteotomi yapıldığı, postop paraplejik olduğunun saptandığı, serviste izlendiği postop 3. gün ameliyata alınarak ameliyat sahasında gözlem yapıldığı, problem görülmediği düşünülerek ameliyatın sonlandırıldığı beyanları bulunmakla birlikte, bu ifadeleri doğrulayan tıbbi belgelerin mevcut olmadığı, postop erken dönemde parapleji görülmesine rağmen gerekli tetkiklerin yapılmayıp zaman kaybedilmesi, ikinci ameliyatın hasta açııından çok önemli olmasına rağmen sadece asistanlar tarafından yapılmış olması, ikinci ameliyat ile ilgili tıbbi belgelerin olmaması, ameliyattan yaklaşık 1 ay sonra yaptırılan torakolomber BT'de birçok seviyede vidaların kanalın içinden geçtiği ve T11 seviyesinde kord basısı olduğu raporu ile belirtilmesine rağmen herhangi bir işlem yapılmamasının bu olayda ihmal ve özen eksikliğinin olduğunu gösterdiği, bu arada sorumluluğun 1. derecede ameliyatı yapan doktora ait olmakla birlikte anılan kişinin talimatıyla yalnızca kendi başlarına ameliyat yetkisi olmayan asistanların girmiş olduğu ameliyatta söz konusu grafilerin incelenmesinde bu 2. ameliyatta asistanların stabilizasyon yapısını değiştirdiklerinin anlaşıldığı ve bu durumun da bir uzmanın gözetiminde olmaması nedeniyle yetkilerini aştığı için izin veren kurum yetkililerinin de sorumlu olduğu saptanmış. Uyuşmazlık konusu olayda, dosyadaki bilgi ve belgelerle yukarıda yer verilen Adli Tıp Kurumu raporundaki açıklamaların birlikte değerlendirilmesinden; davacıların çocuğunun ameliyatlarının gerçekleştirilmesi esnasında yapılması gereken işlemlerin tam ve eksiksiz olarak yapılmayarak gerekli dikkat ve özenin gösterilmemesi nedeniyle davalı idarenin tam olarak (\%100) kusurlu olduğu ve hizmet kusuru doğrultusunda davalı idarenin tazmin borcunun doğduğu ve olay neticesinde, davacının yürüyemez hale gelmesi, bir başka ifade ile felç kalması nedeniyle meydana gelen zararın hukuki sorumluluk kapsamında davalı idare tarafından karşılanması gerektiği sonucuna varılmıştır. Toplam zararın 861,968,50.-TL maddi tazminata hükmedilmesi, geriye kalan 1,088,031,50.-TL miktarın reddi, kabul edilen tazminat miktarına ise davalı idareye başvurunun yapıldı̆̆ı 28.09.2006 tarihinden itibaren yasal faiz uygulanması gerekmektedir.

Davacıların manevi tazminat talebine gelince; takdiren toplam 310,000,00.-TL manevi tazminatın davalı idarece davacılara ödenmesi, fazlaya ilişkin manevi tazminat talebinin ise reddi gerektiği sonuç ve kanaatine varılmıştır. Açıklanan nedenlerle; toplam 1,171,968,50.-TL tazminatın davalı idareye başvuru tarihi olan 28.09.2006 gününden itibaren işletilecek yasal faizi ile birlikte davacılara ödenmesine, 30.09.2011 tarihinde oybirliği ile karar verildi (Erzurum 1. Idare Mahkemesi E: 2007/53, E: 2011/1256 sayılı karar).

Kararın temyiz edilmesi üzerine Danıştay'ın ilgili dairesinin raporunda Adli Tıp Kurumu Üçüncü Adli Tıp ihtisas Kurulunun temyiz istemine konu karara esas alınan rapor doğrultusunda temyiz isteminin reddi ile idare mahkemesinin onanmasına oyçokluğuyla karar verilmiş. Ancak Danıştay'ın ilgili dairesindeki karşı oyların gerekçesi de burada oldukça önem arz etmektedir. Azlık oy'da skolyoz hastası olan davacının ameliyat olmadan önce iş gücü kaybının bulunup bulunmadığı hususunun ek bilirkişi incelemesi yaptırılmak suretiyle açıklığa kavuşturulması gerekmekte olduğunu, bu husus açıklığa kavuşturulmadan davacının \%100 işgücü kaybına uğradığı kabul edilerek hesaplanan maddi zararın tazmin edilmesi yolunda verilen mahkeme kararının eksik inceleme nedeniyle bozulması gerektiği görüşü ile idare mahkemesi kararının bu kısmının onanmasına ilişkin çoğunluk kararına katılınmadığı ifade edilmektedir. (Danıştay 10. Daire 28.03.2012 tarihli E. 2011/11311, K: 2012/1213 sayılı kararı). Söz konusu azlık oyu belirtilmiş ancak Danıştay Erzurum İdare Mahkemesi'nin vermiş olduğu kararı onamıştır.

Danıştay 15. Dairesinin 10.11.2016 tarihli E: 2013/4097, K: 2016/5327 sayılı kararında;

idare Mahkemesi'nce; dosyadaki bilgi ve belgelerin incelenmesi sonrası idarenin yürüttüğü sağlık hizmetindeki eksiklikler nedeniyle meydana gelen zarardan sorumlu olduğu gerekçesiyle davanın kabulüne, hatalı iğne uygulaması sonucu oluşan iş gücü kaybına karşlık 80,000,00.-TL maddi ve 20,000,00.-TL manevi tazminatın davanın açıldığı 16.01.2003 tarihinden 
itibaren işletilecek yasal faizi ile birlikte davalı idarece davacıya ödenmesine karar verilmiştir. Davalı tarafça, temyizen incelenip bozulması istenilmiş, dosyadaki belgeler ile temyiz dilekçesindeki iddiaların incelenmesinden, temyiz istemine konu kararın hukuka ve usule uygun olduğu, kararın bozulmasını gerektirecek yasal bir sebebin bulunmadığı sonucuna varılmıştır. İdare Mahkemesi kararının, maddi tazminat kabulüne ilişkin kısmının incelenmesi; dava dosyasının incelenmesinden; davacının sağ ayak 5. parmak lateralinde şişlik, ayakkabı giyememe, ayakta şekil bozukluğu şikayetleri ile 28.11.2001 tarihinde ...... Hastanesi'ne müracaat ettiği, Ortopedi ve Travmatoloji uzmanı Dr... ... . tarafindan yapılan muayenesinde sağ ayak 5 . metatars lateralinde sert kitle ele geldiği, nörovasküler muayenesinin normal olduğu, radyolojisinde sağ ayağın 5 . metetarsal distal kısmının genişlemiş olduğu, halluks valgus + bunionette ön tanısıyla eksizyon ve traşlama önerisiyle aynı tarihte ortopedi servisine yatırıldığı, yapılan ameliyatla sağ ayak 5. metatarsal distal uç traşlama ve buniektomi uygulanarak taburcu edildiği, davacının ameliyat sonrası sol bacağında kuvvetsizlik, ağrı ve uyuşma şikâyetleri nedeniyle aynı hastanenin nöroloji kliniği raporunda "sol siyatik sinir lezyonu" tanısı koyulduğu, davacı tarafından meydana gelen sinir lezyonunun yapılan hatalı iğne sonucu oluştuğunun öğrenilmesi üzerine açılan tazminat davasının meydana gelişi yukarıda ayrıntılı olarak açıklanan tazminat istemine konu olayda; kişide meydana gelen sol ayaktaki güçsüzlüğün enjeksiyon nöropatisi ile uyumlu olduğu, enjeksiyonun yanlış yere yapıldığına dair tıbbi bir belge mevcut olmadığı, enjeksiyonun doğru yere yapılmış olduğu durumlarda da sinire hasar verebileceği, mevcut tablonun komplikasyon olduğu anlaşıldığından, davalı idarenin hizmet kusurundan söz edilmesi mümkün değildir. Bu durumda, davacının sol ayağında meydana gelen güçsüzlüğün enjeksiyon sonucunda meydana geldiği görülmekte ise de, idarenin maddi tazmin sorumluluğundan bahsedebilmek için hizmet kusuruna ilişkin eylem ile zarar arasında illiyet bağının tespit edilmesi gerektiği, olayda enjeksiyonun yanlış yere veya hatalı uygulandığı yolunda bir tespit yapılmadığı görüldüğünden, olayda davalı idarenin maddi zararı tazmine ilişkin sorumluluğunun bulunmadığı açık olup, idare mahkemesi kararının maddi tazminat talebinin kabulüne ilişkin kısmında hukuki isabet bulunmamaktadır. Açıklanan nedenlerle; temyiz isteminin kısmen kabul kısmen reddine, Ankara 15. İdare Mahkemesi'nin 31.12.2009 tarih ve manevi tazminatın kabulüne ilişkin kısım yönünden onanmasına, maddi tazminatın kabulüne ilişkin kısım yönünden bozulmasına oyçokluğuyla karar verilmiş. Karşı oyda ise İdare Mahkemesi'nce verilen karar ve dayandığı gerekçe hukuk ve usule uygun olup bozulmasını gerektirecek bir sebep de bulunmadığından temyiz isteminin reddi ile İdare Mahkemesi kararının onanması gerektiği görüşüyle çoğunluk kararına katılmadığı şerh düşülmüş.

Danıştay 15. Daire 10.11.2016 tarihli E: 2013/4251 K: 2016/5328 sayılı kararı;

Uyuşmazlık konusu olayda; dosyadaki belgelerin incelenmesinden davalı idareye bağlı hastanede pratisyen hekimin davacıların çocuğunun ilk muayenesini yaptıktan sonra pansuman, yara bakımı ve dikiş için teknisyene yönlendirdiği, parmağa dikiş atılırken hekim hastanın başında bulunmamış olup dikiş sayısının miktarı ve ne kadar sıklıkla atılacağı konusunda teknisyeni yönlendirmemiş olduğu ve küçük bir alana 10 telin sık bir şekilde atılması ve bu durumun parmağın demir kapıya sıkışması sonucu oluşan damar zedelenmesi sonucu oluşan dolaşım bozukluğu durumunu daha da arttırdığı ve parmağın bir kaç gün içinde dolaşım bozukluğu neticesinde kangren olmasına sebebiyet verdiği anlaşılmıştır. Ayrıca idare dikiş atan personelin kim olduğunu da hastane kayıtlarından kayıtların tam olarak tutulamaması nedeniyle tespit edememiştir. Dikiş atan kişinin dikiş atmaya ehil biri olup olmadığı da dosya kapsamından anlaşılamamaktadır. Atanan muhakkik raporunda da bu husus, hastanın başvurusu esnasında hasta acil kayıt defterine kayıt yapılarak uygulanan tedavilerin yazılması gerektiği, bu defterlerin doktorun denetim ve sorumluluğunda olduğu, davacıların çocuğu hakkında bu defterin tutulmadığı ve kayıtların yapılmadığı dolayısıyla savcılığa intikal eden durumlarda kayıtların tutulmaması hangi personelin ne işlem yaptığının tespitinde sorunlar çıkardığı, bunun bir eksiklik olduğu şeklinde vurgulanmıştır. Davacıların çocuğuna hangi personelin dikişi attığının tespit edilemediği gibi, hasta acil konsültasyon formunun dahi düzenlenmediği görülmüş olup hastane kayıtlarını eksik tutan idarenin bu eylemi de sağlık hizmetinin eksik işletildiğini göstermektedir. Olaya ilişkin olarak sorumlu hekimler hakkında açılan ceza davasında alınan 2011 tarihli Yüksek Sağlık Şurası raporunda da hastaya kim tarafından dikiş atıldığının belli olmadığı, atılan dikiş tekniğinin doğru olmadığı, hekimin tedaviye yaklaşımının doğru olmadığı bu tarz yaralanmalarda dikişten önce grafi istenilmesi gerektiği hususları ayrıca vurgulanmış ve ceza yargılamasında hekimler kusurlu bulunmuşlardır. Öte yandan röntgen çekilmediği, röntgen çekilip sonuç görülmeden ve doktor gözetimi ve yönlendirmesi olmadan personelce hastanın parmağına uygulanan telle 10 adet dikiş işleminin bu kadar küçük bir alana sık olarak sayıca fazla dikiş atılmasının yerinde olup olmadığı, zaten var olan dolaşım bozukluğuna etkisi, kişideki dolaşım bozukluğu durumunu daha da ağırlaştırabileceği hususunun irdelenmediği, hekim 
tarafından işlem yapılmadan önce parmağın röntgeninin çekilmesinin talep edilip hastanın parmağının durumu görüldükten sonra ortopedi konsültasyonu da yapılarak ortopedist hekiminin önerisi de alınarak birlikte dikiş işlemine geçilmesinin daha uygun olacağının bu hususların tıbbi uygulamada eksik bırakıldığı görülmüş olup, İdare Mahkemesi tarafından bu hususların açıklığa kavuşturularak gerekirse yeni bir Adli Tıp Raporu alınarak yeni bir karar verilmesi gerektiği, eksik incelemeye dayalı mahkeme kararında bu yönlerden hukuka uyarlık bulunmadığı sonucuna oy birliği ile karar verilmiş.

\section{* $\quad * \quad *$}

Bir diğer Danıştay 15. Dairesi 23.05.2016 tarihli E: 2013/4474, K: 2016/3697 sayılı kararı incelendiğinde davacıların kızının kolunun kırılması üzerine, ... Hastanesi'ne başvurdukları, SSK'lı olmaları nedeniyle hastanın SSK ... Hastanesi'ne sevk edildiği, burada ortopedi doktoru tarafindan ameliyata gerek görülmeyerek kolunun alçıya alındığı, iyileşmeyince... . Hastanesi'ne başvurdukları, burada da ameliyat edilmeyerek konservatif tedaviye devam edildiği, kazanma gücünü kaybedecek şekilde uzuv zaafının meydana geldiği, Trabzon 2. Asliye Hukuk Mahkemesi'nin 2002/117 sayılı dosyasında yapılan incelemede, Yüksek Sağlık Şurası'nın kararı ile hastaya ilk defa müdahale eden doktorun $2 / 8$ kusurlu olduğunu, konservatif tedavilere devam eden... Hastanesi'nin 2/8 kusurlu olduğuna karar verildiği, yaptırılan bilirkişi incelemesi sonucunda 25,832,98-TL'nin doktor ve... Üniversitesi Rektörlüğü'nden zararın tazminine karar verildiği, kararın temyizi üzerine Yargıtay 4. Hukuk Dairesi'nin 06.10.2008 tarih ve E: 2008/241, K: 2008/11172 sayılı kararıyla doktor yönüyle; her türlü tedavi olanaklarının kullanılması halinde dahi tam iyileşme sağlanmasının her zaman mümkün olmadığına ilişkin itirazları da dikkate alınarak ilk anda ameliyat uygulanmış olsaydı tam iyileşmenin mümkün olup olmadığı konusunda rapor alınarak tüm deliller dikkate alınıp bir karar verilmesi gerektiğinden bahisle, davalı ...Rektörlüğü yönüyle; husumetin kuruma yöneltilme sebebinin hizmet kusuru olduğu, hizmet kusurundan doğan zararların giderilmesinin de idari yargının görevinde olduğundan bahisle kararın bozulduğu, mahkemenin görev ret kararı üzerine davacılar tarafından ...Rektörlüğü hasım gösterilmek suretiyle 25,832,97-TL maddi tazminat ile 4,000,00-TL manevi tazminatın ödenmesine karar verilmesi istemiyle görülmekte olan davanın açıldığı anlaşılmaktadır. Davacının tedavisinde hizmet kusuru olup olmadığına ilişkin Yüksek Sağlık Şurası ve Adli Tıp Kurumu 3. Adli Tıp ihtisas Kurulunca düzenlenen ve birbiri ile çelişen iki rapor bulunmaktadır. Yüksek Sağılk Şurası tarafindan düzenlenen raporda, düşme sonucu oluşan sağ ulna kemiği kırığında çocuğun kolunu alçıya alan, bir gün sonra parmaklardaki şişme ve ödem sebebiyle alçıyı açarak kolu atele alan ancak, ikinci gelişinde hastaneye yatırılması gereken hastayı hastaneye yatırmayan ve konservatif tedavilere devam eden doktorun $2 / 8$ oranında kusurlu olduğu, hastanın sevk edilmesinden sonra konservatif tedavilere devam eden ... Hastanesi'nin 2/8 oranında kusurlu olduğu belirtilmiştir. Adli Tıp Kurumu 3. Adli Tıp ihtisas Kurulunca düzenlenen raporda ise 02.08.2001 tarihinde kolunun kırılması nedeniyle alçı tedavisi uygulandıktan sonra 14.08.2001 tarihinde müracaat ettiği... Hastanesi Ortopedi ve Travmatoloji servisinde yapılan muayenesinde, kolunun wolkman iskemik kontraktürü gelişmiş olarak müracaat ettiğinin anlaşıldığı, tedavi programına alındığı, tedavi programına alınarak tenoliz ve FDP(Fleksör Digitorum Profundus) uzatılması ve FDP-BR(Brakioradialis) transferi, daha sonra tenoliz ve ECRL-FPL transferi ve sonrasında da tenoliz yapılarak brakioradialisin FPL transferi, Ekstansör karpi radialis longusun (ECRL) 4. parmak derin fleksörlerine transferi uygulandığı hususları dikkate alındığında kişiye ...Hastanesi Ortopedi ve Travmatoloji kliniğinde yapılan tüm tedavilerin tıp kurallarına uygun olduğu, ayrıca konuyla ilgili ...Ortopedi ve Travmatoloji Anabilim Dalı Başkanının yazısında, hastanın kurumlarına kırık olduktan 12 gün sonra geldiği, sağ radius ve ulna kırığı ile kompartman sendromu sekeli tanıları ile takibe alındığı, kompartman sendromunda acil müdahalenin ilk gün yapılması gerektiği, bu süreden sonraki ameliyatların sekonder girişimler olduğu ve 3-4 aydan sonra yapılmasının uygun olduğu, kurumlarındaki ameliyatların da bu kapsamda 2002, 2003 ve 2005 yıllarında nöroliz, tenoliz, tendon transferi ameliyatları şeklinde yapıldığı belirtilmiştir. Bu durumda, davacının tedavisinde hizmet kusuru olup olmadığına ilişkin birbiri ile çelişen iki rapor bulunması nedeniyle, taraf iddiaları da dikkate alınmak suretiyle alçı ve atel uygulamasının operasyonu geciktiren tıbbi bir müdahale olup olmadığı, Adli Tıp Genel Kuruluna gönderilerek saptanmasından sonra uyuşmazlığın çözümlenmesi gerekirken, eksik inceleme sonucu verilen kararda hukuki isabet bulunmamaktadır. Açıklanan nedenlerle, Trabzon idare Mahkemesi'nin kararının bozulmasına 23.05.2016 tarihinde oybirliği ile karar verilmiş.

Yine Danıştay 15. Daire 23.05.2016 tarihli E: 2013/5356, K: 2016/3705 sayılı kararında;

Dava dosyasının incelenmesinden; davacının araç dışı trafik kazasına bağlı sol bacakta ağrı şikâyetiyle ...Hastanesi Acil Polikliniği'ne müracaat ettiği, 
davacıda sol tibia proksimal kırı̆̆ı tespit edilerek ameliyat edildiği, davacının ameliyat olan bacağında ateş ve ağrı şikâyeti ile hastaneye müracaat etmesi üzerine enfeksiyon bulguları saptanarak yatışının sağlandığı, durumuna uygun tedavi sonucunda şikâyetlerinde gerileme ve iyileşme olması nedeniyle kontrole gelmek üzere taburcu edildiği, davacının daha sonra hastaneye çağrıldığı ve yapılan muayene sonrasında hastanın ayağındaki dril parçasının ameliyatla çıkarılmasına karar verildiği ancak, yüzeysel enfeksiyon olduğu için ameliyatın konsey kararı ile ertelendiği, davacının ise özel bir hastaneye başvurduğu ve burada yapılan ameliyat ile ayağındaki dril parçasının çıkarılması sonrasında ... Hastanesi'nde gerçekleştirilen ameliyatın hatalı yapıldığı ileri sürülerek 10,319,24 TL maddi ve 20,000 TL manevi olmak üzere toplam 30,319,24 TL zararın tazmini istemiyle bakılan davanın açıldığı anlaşıımıştır. Uyuşmazlıkta, Adli Tıp Kurumu 3. ihtisas Kurulu'nca yapılan inceleme sonucunda, ameliyat bölgesinde bir adet matkap ucu çıkarıldığı bildirilen davacıda ortaya çıkan tablonun metal yorgunluğuna bağlı ortopedik ameliyatlarda görülen komplikasyonlardan olduğu, hastaya davalı idareye bağlı hastanede konulan tanı ve yapılan ameliyatın tıp kurallarına uygun olduğunu belirtilerek olayda davalı idarenin hizmet kusuru bulunmadığı gerekçesiyle mahkemece davanın reddine karar verilmiştir. Davacı tarafından, hukuka aykırı olduğu ileri sürülerek, anılan İdare Mahkemesi kararının temyizen incelenerek bozulması istenilmektedir. Danıştay'ın incelemesi sonucunda: ... Hastanesinde konulan tanı ve yapılan ameliyatın tıp kurallarına uygun olduğu belirtilerek, olayda davaIı idarenin hizmet kusuru bulunmadığından davanın reddine karar verilmiş ise de; davacının sol bacağında ... Hastanesinde Ortopedi ve Travmatoloji servisinde yapılan ameliyatında matkap ucunun kırılması suretiyle kırılan parçanın yerinde bırakıldığı anlaşılmaktadır. Bu itibarla, her ne kadar kırılan oyucu matkap ucunun çıkarılmamasının kırık iyileşmesine etkisinin olmayacağı ve eksremitede kısalma veya sakatlığa neden olmayacağı belirtilmekte ise de davacı hastanın vücudunun bir bölgesinde böylesi bir yabancı cisim ile yaşamaya katlanması beklenemeyeceğinden bu yönüyle davacıya uygulanan tıbbi müdahalede sağlık hizmetinin kusurlu işletildiği sonucuna ulaşılmaktadır. Buna göre, İdare Mahkemesince; gerek hastane idaresince temin edilen dril adlı parçanın metal yorgunluğu nedeniyle kırılması gerekse kırılan parçanın ameliyat bölgesinde bırakılması, olayda sağlık hizmetinin kusurlu işletildiğini gösterdiğinden, davacının tazminat istemi hakkında bir değerlendirme yapılarak karar verilmesi gerekirken davanın reddi yolunda verilen kararda hukuki isabet görülmemiştir. Açıklanan nedenlerle, İstanbul 8. İdare Mahkemesi'nin kararının bozulmasına oy birliği ile karar verilmiştir şeklinde sonuç çıkmıştır.

Bir diğer karar örneğinde Danıştay 15. Dairesi'nin 22.10.2015 tarihli E: 2014/9309, K: 2015/6400 sayılı kararında davacının 02.09.2003 tarihinde ağaçtan düşerek yaralanması sonucu kaldırıldığı ...Hastanesi'nde hatalı tedavi uygulanarak \%40 oranında sakat kalmasına neden olunduğundan bahisle uğradığını iddia ettiği maddi ve manevi zararlarının tazmini istemiyle açılmıştır. Samsun 2. İdare Mahkemesi'nce, ... Hastanesi'nde uygulanan tedavi süreciyle ilgili olarak tedavi sürecini yürüten doktor hakkında Samsun Cumhuriyet Başsavcılı̆̆ına yapılan şikâyet sonrasında Adli Tıp Kurumu'na yaptırılan bilirkişi incelemesi sonucu düzenlenen rapor ile dosyada bulunan bilgi ve belgelerin birlikte değerlendirilmesinden, davacının tedavisinde sunulan sağlık hizmetinin kusurlu olduğu sonucuna varılarak, maddi tazminat isteminin kabulü, manevi tazminat isteminin kısmen kabulü, kısmen reddine karar verilmiştir. Olayda, mahkeme kararına dayanak alınan 3. Adli Tıp İhtisas Kurulu'nun raporunda özetle, davacının kalça ve el bileğindeki kırıklar nedeni ile hastaneye yatırıldığı, el bileğine konservatif tedavi uygulandığı, kalçadaki lateral kollum femoris kırı̆̆ına ise Smith Peterson plak vida uygulandığı, kalçada femur başı nekrozuna bağlı komplikasyonlar geliştiği anlaşılmış olup, düşme sonucu meydana gelen el bileğindeki kırık için gerekli tedavinin yapıldığı ve iyileşmiş olduğu, sağ lateral kollum femoris kırığında bölgenin damarsal yapısı itibariyle özellikle ileri yaşlarda kaynamanın mümkün görülmediği, başlangıçta parsiyel protez konmasının daha uygun olacağı, kaynamanın olmayacağını fark edip uygun osteosentez materyali ile gereken tedavisini gerçekleştirmediği cihetle tedaviyi gerçekleştiren doktorun kusurlu olduğu belirtilmiştir.

Davalı idare ve müdahil tarafından, karar düzeltme aşamasında dosyaya sunulan TOTBID (Türk Ortopedi ve Travmatoloji Birliği Derneği) bilimsel görüş incelemesinde, 44 yaşındaki bir kişide lateral kollum femoris kırıklarında parsiyel protez uygulamasının gerektiği seklindeki bir görüşün kesinlikle doğru olmadığının belirtildiği, 44 yasındaki bir kişide, CHS (DHS) çivisinin lateral kollum femoris kırıklarında kullanılmasının doğru bir uygulama olduğu, Smith Peterson çivisinin, CHS (DHS) çivisi olarak değerlendirilmesinin kesinlikle eksik bilgiden kaynaklandığı, söz konusu olan şahıstaki arazın istenmeyen tıbbi bir komplikasyon olduğunun ifade edildiği hususu göz önüne alınarak, davacıya ilişkin dosya yeniden incelenmiştir.

Sağ kollum femoris kırı̆ı̆ sonrasında DHS (Richard çivisi) çivisi ile tespit edildiği halde diğer mütalaada 
sehven Smith Peterson plak vida uygulandığı görüşünden hareketle, doktora kusur izafe edildiği ancak dosyanın yeniden incelenme neticesinde, gerçekte DHS çivisinin kullanıldığı ve şahsın ameliyat olduğunda 44 yaşında olması nedeniyle DHS çivisinin kullanılmasının doğru bir endikasyon olduğu anlaşılmıştır. Bu yaşta parsiyel protez uygulamasının gerektiği şeklindeki görüşün doğru olmadığı, söz konusu CHS (DHS) çivi uygulamasının cari ve tıbbi tedavi yöntemlerinden olduğu dikkate alındığında tedaviyi gerçekleştiren doktora kusur atfedilmediğinin belirtildiği görülmektedir. Bu durumda, davacıya sunulan sağlık hizmetinde kusur olup olmadığı yönünden çelişkili raporlar mevcut olup, davacıya parsiyel protez uygulamasının gerekli olup olmadığı ile davacıya uygulanan tedavide idarenin hizmet kusurunun bulunup bulunmadığının, 2659 sayılı Kanun hükümleri uyarınca dosyanın Adli Tıp Genel Kuruluna gönderilerek saptanmasından sonra karar verilmesi gerekmektedir. Açıklanan nedenlerle, davalı idarenin temyiz isteminin kabulü ile dosyanın yeniden bir karar verilmek üzere adı geçen mahkemeye gönderilmesine oy birliği ile karar verilmiş. TOTBiD'in burada bilimsel görüş bildirerek hatalı bilgi ile ilerleyen davanın seyrini nasıl değiştirdiği açıkça görülmektedir.

\section{* * *}

Başka bir davada İstanbul Anadolu 40. Sulh Ceza Mahkemesi'nce Adli Tıp Kurumu Başkanlığı'ndan alınan raporunda "davacı hakkında düzenlenmiş adli ve tıbbi belgelerde bildirilen veriler Genel Kurulca tekrar değerlendirildiğinde, hastanın... . Hastanesi'ne sağ ayak bilek ağrısı şikâyeti ile başvurduğu, sağ ayak bileğinde talus iskemik nekrozu bulunduğu, tibiotalar, subtalar, talonavikular eklemlerinde artroz tespit edildiği ve doktor tarafından pantalar sağ ayak bilek artrodezi planlanarak yatırıldığı, tetkiklerinin yapıldığı, onam alındığı, anestezi tarafından görüldüğü, allogreft kullanılarak ayak bilek pantalar artrodez ameliyatı uygulandığı, ameliyat sonu alçı tespiti yapıldığı, yara takibinin düzenli yapıldığı, koltuk değnekleri ile yürütüldügü, pansumanının temiz olduğu, ... tarihinde sorunsuz dikişlerinin alındığı kontrollere gelmek üzere taburcu edildiği, kişiye primer ayak bilek kireçlenmesi (artroz) teşhisi ile ortopedi kaynak kitaplar ve literatür dışında kemik allogreft kullanılarak artrodez ameliyatı yapıldığı, kişiye konulan ameliyat endikasyonu doğru olmakla birlikte uygulanan tekniğin güncel tıbbi uygulamalar içerisinde yer almadığı, yapılan ameliyatta allogreft kullanılmasının uygun olmadığı, doktorun bu yönden kusurlu bulunduğu, ancak bu ameliyatın ardından kişiye uygulanan ameliyatlarla hedeflenen amaç olan artrodezin elde edildiği" belirtilmektedir. Dava konusu olayda; davacının maddi tazminat istemi zarara uğradığına ilişkin bilgi ve belge bulunmadığından reddedilmiş ise de; uzuv yitirmesine bağlı oluşan iş gücü kaybından kaynaklı maddi zararının, iş gücü kaybının sağlık kurulu raporu ile tespit edildikten sonra zarar tespit bilirkişi raporu ile hesaplanarak maddi tazminat istemi hakkında bir karar verilmesi gerekirken, bu yönde bir araştırma yapılmadan eksik inceleme sonucu verilen kararda hukuki isabet bulunmamaktadır. Açılanan nedenlerle; davalı idarenin esasa ilişkin temyiz istemi ile davacının manevi tazminatın reddine ilişkin kısmına yönelik temyiz isteminin reddiyle, İstanbul 2. İdare Mahkemesi'nin 24.11.2014 tarih ve E: 2013/2338; K: 2014/2284 sayılı kararının davanın esas ile kabul ve reddedilen manevi tazminata ilişkin kısmının onanmasına, davacının temyiz isteminin kısmen kabulüyle, reddedilen maddi tazminata ilişkin kısmının bozulmasına 04.02.2016 tarihinde oy birliği ile karar verildiği görülmektedir. (Danıştay 15. Daire 04.02.2016 tarihli E: 2015/4695, K: 2016/585 sayılı kararı).

Dava...hastanesinde yapılan ameliyatlarda davalı idarenin hizmet kusuru bulunduğundan bahisle uğranıldığı ileri sürülen 50,000,00-TL maddi ve 60,000,00TL manevi olmak üzere toplam 110,000,00-TL zararın olay tarihinden itibaren işleyecek yasal faiziyle birlikte ödenmesine karar verilmesi istemiyle açılmıştır. Zonguldak İdare Mahkemesi'nce; Adli Tıp Kurumu 2. İhtisas Kurulu raporunun sonuç kısmında; gonartroz tanısıyla sağ dize total diz protezi uygulandığı, daha sonra iki defa sağ dizde kontraktür gelişmesi nedeniyle önce kapalı, sonra açık mobilizasyonun (gevşetme) yapıldığı, daha sonra başka bir sağlık kuruluşunda yara yerinde detaşman gelişmesi nedeniyle debridman ve hiperbarik oksijen tedavisinin uygulandığı, ardından enfekte olan implantın çıkarıldığı, antibiyotikli spacer konulduğu, sonrasında diz eklem arasındaki çimento spacer çıkartılarak debridmanı takiben antibiyotikli çimento ile revizyon diz protezinin yapıldı ğı, kişiye ait sağ diz MR incelemesinin istenilmesine rağmen gönderilmediği, operasyon öncesi yapılan sağ diz MR raporu ve ilgili hekimin ifadesi birlikte değerlendirildiğinde, total diz protezi operasyonu endikasyonunun bulunmadığı dolayısıyla, Ortopedi ve Travmatoloji uzmanının bu yönden kusurlu olduğu, endikasyonu bulunmayan ameliyat sonrası gelişen klinik tablonun kişinin yaşamını tehlikeye sokan bir durum olmadığı, kişi üzerindeki etkisinin basit bir tıbbi müdahale ile giderilebilecek ölçüde hafif olmadığı, sağ dizde protez uygulanmasının organlarından birinin işlevinin yitirilmesi niteliğinde olduğu ... ..." ş̧eklinde mütalaa belirtildiği, ... . Engelli Sağlık Kurulu Raporu ile bu operasyonlar sonucunda davacının \%38 oranında engelli kaldığı, olayda davalı idarenin hizmet kusuru bulunması nedeniyle davacının iş gücü kaybı zararına ilişkin bilirkişi 
incelemesi yaptırıldığı, taraflarca aleyhlerine ilişkin hükümler yönünden hukuka aykırı olduğu ileri sürülerek, anılan idare Mahkemesi kararının temyizen incelenerek bozulması istenilmektedir. Danıştay 15. Daire 13.06.2016 tarihli E: 2016/2846, K: 2016/4378 sayılı kararında davalı idarenin temyiz isteminin kısmen kabulüyle Zonguldak İdare Mahkemesi'nin, miktar artırım dilekçesiyle artırılan tazminat miktarına idareye başvuru tarihinden itibaren faiz işletilmesine ilişkin bölümünün bozulmasına oy çokluğuyla, davalı idarenin temyiz isteminin kısmen reddi, davacının temyiz isteminin reddi ile anılan kararın, diğer kısımlarının onanmasına oy birliğiyle, bozulan kısım hakkında yeniden bir karar verilmek üzere dosyanın anılan mahkemeye gönderilmesine karar verilmiş.

\section{* * *}

Yapılacak her girişim için aydınlatma ve bunun sağlık çalışanı tarafından ispatlanması gerektiğine dair Yargıtay'ın vermiş olduğu bir kararda davacı, düşerek kolunu kırması ile davalı şirketin işlettiği hastaneye tedavi amacıyla gittiğini, ortopedi doktorunun muayenesi sonucu kendisine iğne yapıldığını ve iğne yapılır yapılmaz o anda sağ ayak bileğinin düştüğünü, topallamaya başladığını, bacağında oluşan güç kaybı nedeni ile davalının sorumlu olduğunu ileri sürerek, fazlaya ilişkin hakkı saklı kalmak kaydıyla, 20,000TL manevi 10,000 TL maddi tazminatın faizi ile davalıdan tahsiline karar verilmesini istemiştir. Dava, davacıya davalının işlettiği hastanede hatalı enjeksiyon yapılması nedeniyle oluşan hasar nedeniyle istenilen maddi-manevi tazminata ilişkindir. Sağlıkla ilgili her türlü girişim, kişinin özgür ve aydınlatılmış onamı ile yapılabilir. Alınan onam, baskı, tehdit, eksik aydınlatma ya da kandırma yoluyla alındıysa geçersizdir. Acil durumlar ile hastanın reşit olmaması veya bilincinin kapalı olduğu ya da karar veremeyeceği durumlarda yasal temsilcisinin izni alınır." düzenlemesiyle aydınlatmanın ne şekilde yapılacağı açıklanmıştır. Aydınlatılmış onamda ise ispat külfeti hekim ya da hastanededir. Somut olayda, dosyaya kazandırılan adli tıp raporu ve üniversite öğretim üyelerinden oluşan bilirkişi heyetinden alınan raporda olayın komplikasyon sınırları içinde kaldığı belirtilerek davalının sorumlu olmadığı bildirilmiştir. Ayrıca bilirkişi raporunda, işlemi yapan doktorun işlemle ilgili hastasını bilgilendirmesinin tıbbi kurallara uygun olduğu da belirtilmesine karşın, az yukarıda belirtilen şekilde, davacının yapılan enjeksiyon öncesi, enjeksiyonun komplikasyonları konusunda bilgilendirildiğine ilişkin aydınlatılmış onam düzenlendiği davalı tarafça ispat edilememiştir. Vekil özenle davranma zorunda olup, en hafif kusurundan bile sorumludur. $\mathrm{O}$ nedenle davalı hastanenin meslek alanı içinde olan bütün kusurları, hafif de olsa sorumluluğun unsuru olarak kabul edilmelidir. $\mathrm{O}$ halde, mahkemece bu yön gözetilerek uygun miktarda manevi tazminat takdiri gerekirken, davanın tümden reddi usul ve yasaya aykırı olup, bozmayı gerektirdiği oybirliğiyle karar verildi. (Yargıtay 13. Hukuk Dairesi 07.04.2016 tarihli E: 2015/11729, K: 2016/9861 sayılı kararı)

Kamuda çalışan bir hekimin girişiminin hizmetten sayılıp sayılmaması ile ilgili bir kararda...Devlet Hastanesi'nde görevli ve memur olan davalı doktorun hastası olan davacıya zamanında ve gerekli tedaviyi yapmayarak bir kolunun omuzdan kesilmesine neden olduğu ve doktorun bu eyleminin görevinden ayrılabilir salt kişisel kusura dayandığı iddiası ile eldeki davanın açıldığı, Sağlık Bakanlığı'ndan müfettiş görevlendirilmesinin talep edildiği, müfettişlerce yapılan inceleme sonucunda "diğer iddiaların kanıtlanamadığı, ancak açık kırıklarda ilk 6-8 saat içinde ameliyathane ortamında debridman gerekli olduğu, bunda gecikildiği ve uygulanan antibiyotik tedavisinin de yetersiz kaldığı, doktor hakkında TCK'nın 459. maddesi ile yargılanmak üzere ceza davası açılması gerektiği” görüşüyle fezleke hazırlanıp, verilen 24.11.1994 gün ve 1994/52 sayılı lüzumu muhakeme kararı üzerine de ... Asliye 1. Ceza Mahkemesinin 06.05.1997 gün ve 1995/37 E. 1997/314 K. Sayılı kararıyla Türk Ceza Kanununun 459. maddesi gereğince cezalandırıldığı, bu kararın denetimden geçerek onandığı dosya kapsamı ile bellidir. Ceza mahkemesi kararının dayanağı Yüksek Sağıı Şurası'nın davalı doktor hakkındaki kararın debridmanında gecikilmekle birlikte antibiyotik tedavisinde de geç kalındığı, bu nedenle 2/8 kusurlu olduğu" yönündeki kararıdır. Unutulmamalıdır ki davacı ceza davasına müdahil olarak katılmış ve orada şahsi hak talebinde bulunabilecekken ceza yargılamasının devamı sırasında eldeki davayı açmıştır. Bu olgular karsısında davalı doktorun salt idari bir görevin yerine getirilmesi sırasında zarara yol açmayıp, idari görevi cümlesinden olmakla birlikte hekimlik sanatının icrası sırasında hakkında verilip kesinleşen mahkûmiyet kararıly da belirlenen ve görevinden ayrılabilen salt kişisel kusuru ile davacı zararına yol açtı̆̆ında duraksama bulunmamaktadır. Bir başka bakış açısıyla doktorla hasta arasındaki ilişki yönünden olay ele alındığında ise; öğretide ve yargı kararlarında memur ve kamu görevlisi doktorla hasta arasında kabul edilen iki çeşit ilişki söz konusudur. Bunlardan ilki kamusal ilişkidir. Bu ilişkide memur olan doktor görevini yaparken bir takım idari kurallarla bağlıdır ve bu bağlıık hastayı tedavi zorunluluğunun kişinin rızasını gerektirmediği tıbbi el atma$\operatorname{lar}$ (zorunlu aşı gibi ya da aids hastalı̆̆ında olduğu gibi kamu sağ|ı̆̆ının gerektirdiği hallerde) ve tıbbi el atma ve yardımı gerektirmeyen rapor düzenlenmesi gibi hallerde söz konusudur. Bu gibi idari görev ve yetkilerini 
kullanırken doktor kusurlu eylemiyle bireylere zarar vermişse burada Anayasa'nın 129/5 maddesinin uygulanacağından kuşku bulunmamaktadır. Ancak somut olay bu yönü ile de ele alındığında davalı doktor kusurlu hareketiyle bireye zarar vermesi eylemi nedeniyle ceza mahkemesinde yargılanmış ve ceza almıştır. Doktor ceza mahkemesinde yargılanıp mahkûm olduğuna göre artık Anayasa'nın 129/5. maddesindeki memuru korumak amacı ortadan kalkmış, diğer taraftan da zarar gören kişi memura karsı kişisel sorumluluğa giderek dava açmıştır. Bu noktada sorunun anılan maddeye göre çözümlenmesi özsel olmaktan çok biçimsel bir yorum olur. Yeri gelmişken şunu hemen ifade etmek gerekir ki, memurun kasıtlı eylemi ile taksirli eylemi arasında kişisel kusurun varlığı noktasında bir farklılık bulunmamaktadır. İkinci ilişki ise sözleşme ilişkisi olup, bunun üzerinde de durmakta yarar vardır. Kişinin yaşam ve sağlığı onun kişisel değerlerini oluşturur. Kişilik hakkının korunduğu bu değerlere el atılması ancak tıbbi tedavi amacıyla ve doktorla hasta arasında oluşturulan bir sözleşmeyle yani izinle mümkündür. Doktorla hasta arasındaki sözleşme ilişkisi kurulduktan sonra Anayasa'nın 129/5. maddesinin uygulanmaması ve doktora karşı doğrudan dava açılabilme olanağının varlığının kabulü gerekir. Çünkü zarar, memur ya da kamu görevlisi olan doktorun idari yetkilerini kullanırken değil tıp bilimi kurallarına göre yapılan tıp sanatının uygulanması sırasında meydana gelmektedir. Tüm bu açıklamalar ışığında mahkemece davalı doktorun eyleminin görevinden ayrılabilir bir eylem olmadığı, bu nedenle hakkında dava açılamayacağı, husumet ehliyetinin bulunmadığı gerekçesiyle verilen direnme kararı usul ve yasaya aykırı olup, bozulması gerekmiştir. (Yargıtay Hukuk Genel Kurulu 26.09.2001 tarihli E: 2001/4-595, K: 2001/643 sayılı kararı).

Yukarıdaki kararla farklılığı bulunan bir karar da Yargıtay 4. Hukuk Dairesi tarafindan 2012 yılında verilmiştir. Bu kararda dava, hatalı tedavi nedeniyle uzuv zaafı oluşmasından dolayı uğranılan maddi ve manevi zararın tazmini talebine ilişkindir. Davacı, ayağına dikiş iğnesi battığından tedavi için başvurduğu... Hastanesi ortopedi servisinde davalı doktorun müdahale ve tedavileri sonucunda bacağının sakat kaldığını belirterek tazminat talebinde bulunmuş; davalı Anayasa'nın 129. maddesi gereği kendisine husumet yöneltilemeyeceğini savunmuş, mahkemece dava kısmen kabul edilmiştir. Kamu görevlilerinin yetkilerini kullanırken veya görevlerini yaparken kişilere zarar vermesi ilgili kamu kurumunun hizmet kusurunu oluşturur. Bu durumda sorumlu, kamu görevlisinin emrinde çalışmakta olduğu kamu kurumu olup dava o kurum aleyhine açılmalıdır. (T. C. Anayasası 40/III, 129/V, 657 Sy. K. 13, HGK 2011/4-592 E., 2012/25 K.) Bu konuda yasal düzenlemeler emredici hükümler içermektedir. Diğer yandan sorumluluk hukukunun temel ilkeleri açısından bakıldığında da bu şekilde düzenlemenin mevzuatta yer almış olması zarar görenin zararının karşılanması yönünde önemli bir teminattır. Davaya konu edilen olayda; ... Hastanesi'nde uzman hekim olan ve kamu görevlisi sıfatını taşıyan davalının, görevini yerine getirmediği ileri sürülerek tazminat isteminde bulunulmuştur. Yukarıda açıklanan ilkeler ışığında, davanın idari yargı yerinde ve idareye karşı açılması gerekir. Davalıya husumet yöneltilemez. Husumet yokluğu nedeniyle davanın reddi yerine, işin esasının çözümlenmesi doğru görülmemiş ve bozmayı gerektirmiştir (Yargıtay 4. Hukuk Dairesi 09.10.2012 tarihli E: 2012/8855, K: 2012/14694 sayılı kararı).

Yargıtay 13. Hukuk Dairesi 08.02.2001 tarihli E: 2001/380, K: 2001/1303 sayılı kararında davacı, sağ kol bilek kısmında meydana gelen kırık sebebiyle tedavi için davalı şirkete ait... hastanesine başvurduğunu, kolunun ameliyat edilip 5 gün hastanede tutulmasına rağmen gereken tıbbi tedavi yapılmadığından kolunun şişip kangrene dönüştüğünü, hastaneden ayrılıp... . Tıp Fakültesi Hastanesi'ne gittiğini, orada kangren teşhisi konulup kolunun bilek ile dirsek arasından kesildiğini, zararlı sonucun davalı işletmenin kusur ve ihmalinden kaynaklandığını ileri sürerek fazlaya ilişkin hakları saklı kalmak kaydı ile iyileştirme giderleri, iş ve beden gücü kaybı karşılığı ve protez için şimdilik $250,000,000 \mathrm{TL}$. tazminatın olay tarihinden itibaren reeskont faizi ile birlikte davalıdan tahsiline karar verilmesini istemiştir. Davalı, olayın 1995 yılında meydana geldiğini, davada bir yıllık zaman aşımı süresinin gerçekleştiğini, öncelikle davanın bu yönden reddine karar verilmesini, esas yönden de davalının kolunu patoza kaptırdığını, meydana gelen kırıklar nedeniyle hastaneye başvurduğu tarihte kolunun kesilmesi gerektiğini, ancak inceleme sonucu gazlı gangren hücrelerine rastlanmadı̆̆ından kolun tedavi ile kurtarılmaya çalışıldığını, ancak dokuda beslenme olmadığından kolun kesilmesinden başka çare kalmadığını, durum kendisine bildirildiğinde davacının buna razı olmadığını, amcasının gelip röntgen filmleri ile birlikte davacıyı alarak Ankara'ya götürdüğünü, görevin gereği gibi yerine getirildiğini, kusur bulunmadığını beyan ile davanın esas yönden de reddini savunmuştur. Yerel mahkemece, olayda davalının kusurunun bulunmadığı, özen görevinin tam olarak yerine getirildiği kabul edilerek dava reddolunmuş; hüküm davacı tarafından temyiz edilmiştir. Davacının kolunu patoza kaptırması sonucu kırıldığı, davalıya ait... hastanesinde cerrahi müdahalede bulunulduğu, kolunun kötüleşmesi nedeniyle hastaneden ayrılıp... . Tıp Fakültesi Hastanesi'ne başvurduğu, burada kolunun kesildiği uyuşmazlık konusu değildir. Uyuşmazlık davalıya ait 
hastanedeki ilk tedavinin tıbbın gereklerine uygun yapılıp yapılmadığı, olayda doktor hatası olup olmadığı noktasında toplanmaktadır. Taraflar arasındaki ilişki bir vekâlet ilişkisidir. Dava özen borcuna aykırılık iddiası ile açılmıştır. Vekil (doktor) işini yaparken bir işçi gibi özen göstermek zorundadır. (BK: s. 386-390, 321) bu nedenle en hafif kusurundan dahi sorumludur. Doktor hastalığa tıbbı açıdan zamanında ve gecikmeksizin doğru teşhisi koymalı, önlemleri eksiksiz biçimde ve gecikmeksizin almalı, olayın gerektirdiği uygun tedaviyi gecikmeden belirleyip uygulamalıdır. Tıbbın gerek ve kurallarına uygun davranılmakla birlikte sonuç değişmemiş ise doktor sorumlu tutulamaz. Mahkemenin kararına dayanak yaptığı 23.06.2000 tarihli el cerrahisi, Ortopedi ve Travmatoloji uzmanlarından oluşan bilirkişi kurulu raporunda, olayın oluşumu ve uygulanan tedaviden söz edilip, ... bunun ortopedi uzmanlığını almış her ortopedist tarafından yapılabilmesi nedeni ile tıbbi hata düşünülmemiştir denilmiştir. Raporda, somut olaydaki gibi bir kırıkta, tıbbın gereklerine ve kurallarına uygun teşhis ve tedavi yöntemlerinin uygulanıp uygulanmadığı, bu konuda yukarıda açıklanan ilkeler doğrultusunda özen gösterilip gösterilmediği, yapılması gerekenle, yapılanın uyuşup uyuşmadığı açıklamalarına yer verilmemiştir. Açıklanan hususlar gözetilmeksizin eksik araştırma ve incelemeye, yetersiz bilirkişi raporuna dayanılarak yazılı biçimde hüküm kurulması usul ve yasaya aykırı olup bozmayı gerektirir.

Yargıtay 4. Ceza Dairesi 11.02.2004 tarihli E: 2003/1064, K: 2004/2055 sayılı kararında;

Trafik kazası sonucu hastane acil servisine getirilen ölenin, yapılan ilk müdahaleden sonra yatırıldığı ortopedi servisinde görevli sanık doktor ile hemşirenin uzun süre geçmesine rağmen zamanında ve yeterli kontrolmuayene ile ölende gelişen klinik bulgulara uygun gerekli müdahaleyi yapmak ya da yapılmasını sağlamaları gerekirken bunu yapmamaları nedeniyle Yüksek Sağlık Şurası'nın kararı ile ölüm olayında her bir sanığın 4/8 oranında kusurlu bulunduğunun belirtilmiş olması karşısında; dosya ile birlikte, ölen ile ilgili tüm raporlar ile hastane kayıt ve belgeleri gönderilmek suretiyle, Adli Tıp Kurumu'ndan sanıkların tedavide kusurveya savsamalarının bulunup bulunmadığı, bulunduğu saptandığı takdirde yükletilen savsama niteliğindeki eylemler ile ölüm arasındaki illiyedin belirlenmesine yönelik olarak, sanıkların kendilerine yasal normlar çerçevesinde yükletilen sorumluluklarını yerine getirmeleri durumunda dahi ölüm olayının gerçekleşip gerçekleşmeyeceğine ilişkin görüş alınarak; sanıkların bu yöndeki sorumluluklarını yerine getirmiş olmaları halinde yine de ölüm olayı kaçınılmaz biçimde gerçekleşeceği sonucuna varılması durumunda, eylemlerinin görevi savsama suçunu; ölüm olayının gerçekleşmesinde, sanıkların kendilerine yükletilen sorumluluklarını yerine getirmemelerinin etkili olduğu sonucuna varılması durumunda da taksirle ölüme neden olmak suçunu oluşturacağı ve kusur oranlarına göre cezalandırılmaları gerekeceği gözetilmeden, eksik soruşturmayla görevi savsama suçundan hüküm kurulması, yargılamanın bozma öncesi aşamadan başlayarak sürdürülüp sonuçlandırılmak üzere dosyanın esas/hüküm mahkemesine gönderilmesine oybirliği ile karar verildi.

Yargıtay 5. Ceza Dairesi 30.01.2014 tarihli E: 2012/11042, K: 2014/1038 sayılı kararında;

Iddianame içeriğinde özetle "Suç tarihinde... Devlet Hastanesi'nde ortopedi uzmanı olarak görev yapan sanığın, geçirdiği trafik kazası nedeniyle hastaneye getirtilen katılanın vücudundaki yara ve kemik kırıklarının bir kısmını teşhis edip tedavi etmekle birlikte, sol femur boynu kırı̆̆ını muayene ve röntgen filmiyle tespit edemediği, katılanın taburcu olduktan sonra ağrılarının devam etmesi üzerine... Üniversitesine giderek muayene olduğu ve sanığın tespit edemediği kırık nedeniyle ameliyat geçirdiği, sanığın katılanın muayenesi sırasında gerekli dikkat ve ihtimamı göstermeyerek görevini ihmal ettiği" iddia edilmiş ve sevk maddesi olarak 5237 sayılı TCK'nın 257/2, 53. maddeleri gösterilmiş ise de, Adli Tıp Kurumu İhtisas Kurulu raporunda katılanın tedavisi sırasında pelvis filmi çektirilmesi halinde parçalı intertrokanterik kırı̆ıı tespitinin mümkün olduğu, söz konusu filmin çekilmemesinin tıp kurallarına uygun olmadığı kanaatinin bildirildiği, ihmal suretiyle görevi kötüye kullanma suçunun kasıtla işlenebileceği, iddianame anlatımının ise taksirle yaralama suçuna uyduğu, Yargıtay Kanununun 14. maddesi ve yukarıda açıklanan Ceza Daireleri Başkanlar Kurulu kararlarında ortaya konan ilkeler doğrultusunda, tesis edilen hükmün incelemesini yapmakla görevli dairenin belirlenmesinde, yanlış gösterilen sevk maddelerinin değil vasfı iddianame metninde açıkça anlatılan suçun dikkate alınması gerektiği ve bu durumda temyiz inceleme görevinin Yüksek 12. Ceza Dairesine ait olduğu anlaşıdığından dairemizin görevsizliğine, dosyanın ilgili daireye gönderilmesine, 30.01.2014 tarihinde oybirliğiyle karar verildi. Söz konusu karar Yargıtay'ın ilgili dairesinin görevsizliği üzerine verilmiş olmakla birlikte hekime atfedilen suç açısından önem arz etmektedir.

Yargitay 12. Ceza Dairesi 30.06.2014 tarihli E: 2013/16064, K: 2014/16108 sayılı kararında;

Ölenin trafik kazası sonucu, ... Hastanesi'ne yatırıldığı, burada tedavisi için gerekli ekipman bulunmadığı 
gerekçesi ile sevki için... Üniversitesi Hastanesi ortopedi servisinin nöbetçi asistanı sanığın arandığı, sanığın da icapçı doktor sanığı telefonla aradığı, yoğun bakımda boş yatak olmadığının anlaşılması üzerine, sanığın hastanın... Hastanesinde yoğun bakım şartlarında bakılmasının iyi olacağı, boş yatak olmadığından sevkinin uygun olmayacağı, İzmir'e gönderilmesi halinde yolda ölebileceğini söylediği, sanığın bu görüşleri... . Hastanesi Ortopedi ve Travmatoloji bölümünde görevli doktora aktardığı, hastanın durumunun kötüleşmesi üzerine... Hastanesi'nden... Tıp Fakültesi Hastanesi'ne sevk edildiği, buradaki müdahalelerin ardından hastanın öldüğü; olay nedeni ile düzenlenen Yüksek Sağlık Şurası'nın raporu gereğince, yoğun bakım servisinde boş yatak bulunmaması nedeni ile üniversite hastanesinde görevli olan sanıkların kusurlarının bulunmadığına ilişkin mahkemenin kabulünde isabetsizlik görülmediğinden tebliğnamedeki bozma düşüncesine iştirak edilmemiştir.

Sonuç: Yapılan yargılama sonunda, suç açısından faillerin taksirinin bulunmadığı gerekçeleri gösterilerek mahkemece kabul ve takdir kılınmış olduğundan, katılan vekilinin, 1219 sayılı Tababet ve Şuabatı Sanatlarının Tarzı İcrasına Dair Kanun'un 75. maddesinin Anayasa Mahkemesi tarafindan iptal edilmesi nedeni Yüksek Sağlık Şurası tarafından düzenlenen raporun hükme esas alınamayacağına, eksik incelemeye, kusurlu olan sanıkların eylemlerinin TCK'nın 83. maddesinde düzenlenen suçu oluşturduğuna ilişkin temyiz itirazlarının reddiyle, sanıkların beraatlarına ilişkin hükümlerin isteme aykırı olarak onanmasına oy birliği ile karar verildi.

Adli Tıp Kurumu'nun iki ihtisas kurulu arasındaki birbirinden farlılık arz eden raporuna istinaden Yüksek Sağlık Şura'sına gönderilen bir dosyada; katılanın geçirmiş olduğu trafik kazası nedeniyle sağ femur orta diafiz ve sol femur kırığı tanısı ile kaldırıldığı hastaneden acil patoloji düşünülmediğinden kendi isteği ile sanığın çalıştığı... Hastanesine sevk edildiği, ortopedi uzmanı olan sanık tarafından ameliyata alınarak katılanın, sol femur suprakondiler kırığı için kapalı redüksiyon ve uzun bacak alçı, sağ femur diafiz kırığına kilitli intramedüller çivi uygulaması yapılıp önerilerle birlikte taburcu edildiği, kontrol muayenelerinin sanık tarafından yapıldığı, ancak sanığın işine son verilmesi nedeni ile hastaneden ayrılmasından sonra, katılanın kontrolünün belirtilen hastanede yeni göreve başlayan doktor tarafından 15 gün süre ile yapıldığı, katılana sağ bacaktaki kırığın kaynamaya başlaması nedeniyle koltuk değneklerini tamamen bırakması ve sağ bacağının üzerine tek değnekle basarak yürümesi gerektiği şeklinde öneride bulunulduğu, katılanın sağ bacağındaki ağrı ve şişlik nedeniyle aynı hastaneye gitmek istediğinde, önce adı geçen doktorun izinli olduğunun, sonra da görevden ayrıldığının belirtilmesi üzerine 10 gün süreyle yeni bir doktorun gelmesini beklediği, 18.03.2008'de fizik tedavi uzmanınca yeni bir kırıktan şüphelenilerek ortopedi uzmanına yönlendirildiği, evvelce konulan implantın kırılmış olduğu saptanarak ameliyat önerisi üzerine, ... Hastanesinde yeniden ameliyat edilmesi neticesinde; katılanın organlarından birinin işlevinin sürekli zayıflaması niteliğinde yaralandığı, kusur durumuna ilişkin Adli Tıp Kurumu 3. İhtisas Kurulu tarafindan 21.06.2010 tarihinde düzenlenen raporda, kusur değerlendirmesi yapılmaksızın 10 mm (olması gerekenden ince) çivi çakıldığı bilateral femur kırığı olması nedeniyle sola da operatif tedavinin tercih edilmesinin gerektiği, ancak alçılı tedavi tercih edildiği, takiplerinde solda alçı olması nedeniyle sağa ister istemez yük vermek zorunda kaldığı, postop 7. ay içinde tek değneğe geçilerek yön verildiği, bu esnada sol alt ekstremite gerektiği biçimde kullanılamadığı için implantın distal çivi seviyesinden kırılması sonucu sağda refraktür meydana geldiği, kırığın iki taraflı olması, soldan gerektiği gibi destek alınamaması ve sağda implant kırılması ve refraktür meydana gelmesi hususunun kırık sonrası görülmesi beklenir komplikasyonlar arasında sayılmasının uygun görüldüğü şeklinde görüş bildirdiği, Adli Tıp Kurumu 2. İhtisas Kurulu'nca düzenlenen sağ femur diafiz kırığına kilitli intramedüller çivi, sol femur kırığı için kapalı redüksiyon ve alçı tespiti girişimlerinin endikasyonu bulunduğu ve yapılan tedavi yönteminin usule uygun olduğu, takiplerde sağ femur kırı̆ıındaki kaynamanın yetersiz olduğu, soldaki kırık nedeniyle sol uyluğun alçı içinde oluşunun ayakta durma ve özellikle yürüme esnasında sağ tarafa daha fazla yük bindirmeyi gerektirdiği, metal implantlarda yorgunluğun söz konusu olduğu ve tüm bu nedenlerle sağ femurdaki çivinin kırılabileceği, ayrıca çivinin kırıldığı dönemde bu hastanedeki görevinin sona ermesi nedeniyle... . doktorun hastasını takip ve kontrol imkânının bulunmadığı ya da kısıtlı olduğu, femur ameliyat materyalinin kırılması sonucu farklı bir klinikte ameliyat edildiği, oluşan plak kırılmasının kırığın bir komplikasyonu olduğunun ve kırık kaynamasına sistemik ve genel faktörler olarak çoklu faktörlerin etki ettiğinin bilindiği, kaynama durumuna kadar kullanılan ameliyat malzemelerinin yük taşıdığı, zamanla kaynama gerçekleşmezse tüm ameliyat malzemelerinin kırılabileceği cihetle doktora atfedilebilecek ihmal ya da kusur bulunmadığı, daha sonra yapılan ameliyat ve tedavilerin tıp kurallarına uygun olduğu şeklindeki görüşü ile sanı̆̆ın kusurunun bulunmadığının bildirildiği hususu nazara alınarak, raporlar arasındaki çelişkinin giderilmesi için tüm dosyanın Yüksek Sağlık Şurası'na gönderilerek, sanık tarafindan katılana uygulanan tedavinin yerinde olup olmadığı, katılanın sağ ayağına takılan 
implantın kalınlığının yaralanma niteliği için yeterli olup olmadığı, sanığın hastaneden ayrılmasının netice üzerinde etki oluşturup oluşturmadığı da belirlenmek suretiyle düzenlenecek raporun sonucuna göre sanığın hukuki durumunun takdir ve tayini gerekirken, yazilı şekilde eksik inceleme ile hüküm kurulmasından dolayı hükmün bu sebepten dolayı bozulmasına oy birliği ile karar verildi (Yargitay 12. Ceza Dairesi 19.06.2014 tarihli E: 2013/17828, K: 2014/15298 sayılı kararı).

Yargıtay 13. Hukuk Dairesi 13.12.2013 tarihli E: 2013/29954, K: 2013/31321 sayılı kararında;

Davacı yüksekten düşme sonucu, ayağında kırık olması nedeniyle tedavi amacıyla... Hastanesi'ne başvurduğunu ve acil servisinde çekilen röntgenlerle birlikte daha iyi bir tedavi göreceği umuduyla, davalı özel hastaneye yatırıldığını, davalı doktor tarafından ameliyat edildiğini, ameliyattan bir süre sonra yürümek istetildiğinde yürüyemediğini, tekrar çekilen filminde femur boyun kırığının tespit edildiğini, doktorlara danışıldığında, sakat kalma tehlikesinin bulunduğunu, bunun üzerine... Hastanesine gittiğini, yapılan kontrollerde ameliyatta gerekli dikkat ve özenin gösterilmediğini, özellikle çekilen tomografilerde ayak bileği kemiklerinden talus kemiğindeki kırı̆ı̆ın görülemediğini, yapılan yanlış ameliyat sonucu ayağını kaybetme tehlikesi bulunduğunu, ayrıca ameliyatta orijinal çivi kullanılmadığını ileri sürerek fazlaya dair haklarının saklı kalmak kaydıyla 10,995,00 TL maddi ve 5,000,00 TL manevi tazminatın davalılardan müştereken ve müteselsilen tahsiline karar verilmesini dilemiştir. Davalı doktor davacıya ameliyatın kendi tarafından yapılmadığını, aynı hastanede çalışan ortopedi uzmanı diğer doktor tarafından gerçekleştirildiğini, davanın husumet nedeniyle reddini, esas yönünden de reddini dilemiştir. Davalı ... Sağlık Hizmetleri Ltd. Şti. nde, davacının hastaneye geldiğinde çekilen röntgenlerden anlaşılacağı üzere, femur boynunda herhangi bir kırık ya da çatlak bulunmadığını, daha sonraki röntgen görüntülerinde böyle bir kırığın ikinci bir darbeye maruz kaldığını gösterdiğini, talus kırığına ilişkin beyanlarının gerçeği yansıtmadığını, yapılan ameliyatla da ilgisi bulunmadığını, sahte çivi kullanıldığı iddialarının da doğru olmadığını, davanın reddini dilemiştir. Yerel mahkemece, davalı ... hakkında açılan davanın feragat nedeniyle reddine, diğer davalı hastane işleticisi olan şirket hakkındaki davanın ise, adli tıp raporu nazara alınarak kusur izafe edilemeyeceğinden bahisle reddedilmiş, hüküm davacı tarafından temyiz edilmiş, verilen karar dairemizce onanmış, davacı bu kez karar düzeltme isteminde bulunmuştur. Sağlık memuru ve hastanenin meslek alanı içinde olan bütün kusurları, hafif de olsa, sorumluluğun unsuru olarak kabul edilmelidir. Somut olayda Adli Tıp raporunda, (sh. 6), şahsın dosyada olan grafide kalça ve femurun görüldüğü, femur diafizde kırığın mevcut olduğu, kollum femoriste kırık hattının tespit edilemediği, yine diğer bir grafide femur boynunda kırık hattının görülemediği, intramedüler çivinin üzerinde olduğu grafi resminde kollum femoriste kırık hattının görülemediği, femur diz dahil grafisinde intramedüler çivinin alt ucunun görüldüğü, ayak bilek AP-Lat grafide ayak bileğin alçı atel ile tespitli olduğu, lat grafide talus kırığının görüldüğü, AP grafide alçı ile süperpoze olduğundan talus kırığının seçilemediği, ayak bilek BT'sinde talus kırı̆̆ı kaynamasının yeterli olmadığının görüldüğü, dosyadaki iki adet kalça dahil femur grafilerinde her ikisinde de intramedüler çivinin görüldüğü, grafilerden bir tanesinde femur boynuda kırık hattının görülemediği, diğerinde femur boynunda kırık hattının görüldüğü belirtilmiş, sonuçta ise ameliyattan 45 gün sonrası çekildiği ifadelerde belirtilen, üzerinde çivi olan kalça dahil femur grafisinde kırık kenarlarının küntleştiği ve minimal kaynamanın başladığı ve aynı filmde kollum femoriste ayrılmış kırık hattının görüldüğü, kollum femoriste oluşan kırığın, ameliyattan 45 gün sonrası çekildiği ifadelerde belirtilen grafide görülmesi kırığın ameliyat sonrası maruz kalınabilecek herhangi bir travma ile oluşabileceğinin kabulü gerektiği, üzerinde kod numarası bulunan çivinin femur ve humerus kırıklarında kullanıldığı, sahte olup olmadığının imalatçı veya ithalatçı firmadan araştırılabileceği, davalı doktora ve hastaneye kusur izafe edilemeyeceği mütalaa olunmuş ve mahkemece de bu rapora itibar edilerek hüküm tesis edilmiştir. Oysa az yukarıda da açıklandığı üzere, hastane yönetimi kayıtların tutulmasından sorumlu olup, ibraz olunan ve tarihsiz çekilen filmlerin hangi hastanede çekildiğinin araştırılmak suretiyle, davalı hastanede çekildiğinin anlaşılması durumunda üzerinde tarih bulunmamasının hastanenin kusurundan kaynaklandığının kabul edilmesi gerektiği gibi, Adli Tıp raporunda, ameliyattan 45 gün sonra çekildiği ifadelerde belirtildiğinden, bu ifadelerin davalı tanıklarının beyanlarına göre bu saptamanın yapıldığı, oysa tanıkların ifadelerine itibar edilemeyeceği, davacı tarafın Adli Tıp raporuna itirazları da dikkate alınarak gerekirse üniversitelerin ilgili kürsülerinden (Ortopedi ve Travmatoloji, radyoloji) seçilecek akademik kariyere sahip bilirkişi heyetinden rapor alınarak, kayıtların düzenli tutulmasından davalı hastanenin sorumlu olduğu da gözetilerek hasıl olacak sonuca uygun bir rapor alınması gerekirken, eksik incelemeyle ve yetersiz Adli Tıp raporuna dayalı olarak hüküm tesisi usul ve yasaya aykırı olup, bu sebeple kararın bozulmasına karar verilmiştir.

\section{* * *}

Yargitay Genel Kurulu'nun vermiş olduğu bir kararda sıkışarak yaralanma üzerine sanık doktorların görevli olduğu... Hastanesi'ne kaldırıldığı, burada çeşitli branşlarda asistan veya uzman doktor olarak görev yapan 
sanıklarca çeşitli tetkik ve değerlendirmelerden sonra aynı gün saat 18:00 sıralarında hastaneden taburcu edildiği, yakınlarının hastanın durumunun kötü olduğunu söyleyerek karşı çıkmaları üzerine acil serviste görevli sanık tarafından ortopedi ve üroloji bölümlerine yönlendirildikleri, ortopedi bölümünde ortopedik olarak acil cerrahi bir müdahaleye gerek olmadığından yatış yapamayacaklarının söylendiği, akabinde gittikleri üroloji bölümünde de üroloji uzmanının bulunmaması nedeniyle sonuç alamadıkları, hastanın yakınları tarafından kiralanan bir ambulansla önce polis merkezine götürülüp orada ifadesinin alınmasından sonra evine ulaştırıldığı, eve varmalarından sonra, hastanede iken öleni muayene eden üroloji uzmanı sanık doktorun telefonla hasta yakınlarını arayıp hastanın idrar yapıp yapmadığını sorduğu, ona hastanın henüz idrar yapmadığını üroloji bölümündeki doktorlarca görülmeden hastaneden çıkartıldıklarını anlattıkları, onun da hastanın idrarını kendisinin yapabileceğini bir sorun olursa pazartesi günü polikliniğe getirmelerini söylediği, sonra hastanın evde yediği yemeği istifra ederek çıkarması nedeniyle yakınlarının hastaneye ulaşmaya çalıştıkları, tam bu sıralarda kazaya karışan kamyonun sahibi olan şirketin görevlilerinin öleni ziyarete geldikleri ve kendi şirketlerinin doktorundan faydalanabileceklerini söyledikleri, şirket doktorunun bulantıya ilişkin verdiği ilaçlar kısa süreli rahatlama sağlasa bile yemek yediğinde aynı sorunu yaşadığı, ölenin yakınlarının gece 01:00 sıralarında... Hastanesi'ni arayıp hastanın kusmalarının ara ara devam ettiğini ve idrarının kanlı geldiğini söyledikleri, hastane görevlisinin onlara o an için üroloji doktoru olmadığını gerekirse başka bir hastaneye götürebileceklerini ifade ettiği, daha sonra tekrar rahatsızlanması üzerine ölenin yakınlarının tekrar ...Hastanesini aradıklarında görevlinin hastayı daha önce götürmüş oldukları hastaneye götürmelerini tavsiye ettiği, ...Hastanesine ulaşmaya çalıştıkları sırada hastanın kötüleştiği ve gözlerinin kaydığı, ancak bu durumun hastanın önceden müptela olduğu epilepsi hastalığından kaynaklanmış olabileceğini düşündükleri ve 112 acil servisi arayıp ambulans istedikleri, saat 10:00 sıralarında eve gelen ambulans görevlilerinin hastanın öldüğünü tespit edip şok tedavisi ile hayata döndürmeye çalıştıkları ancak sonucun değişmediği, ölü muayene işleminde klasik otopsi yapılmasına karar verildiği, klasik otopsi işleminde "sağ akciğerin kaplan postu görünümde olduğu, sol akciğerin ise soluk olup yüzey ve kesitlerinde bir özellik görülmediğinin ve kişinin ölümünün, trafik kazasıyla husule gelmesi mümkün künt genel beden travması sonucu çok sayıda kot ve etraf kırıklarıyla karakterli iç organ yaralanmalarından gelişen iç kanama sonucu meydana geldiği" hususunun tespit edildiği, Adli Tıp Kurumu 1. Ihtisas Kurulu tarafindan düzenlenen raporda; otopsideki makroskopik akciğer bulgularına göre kişinin ölümünün göğüs ve batın travmasına bağlı kot fraktürleri, pelvis fraktürü ve gelişen komplikasyonlar (akciğer embolisi) sonucu meydana gelmiş olduğunun bildirildiği, olay tarihinde genel cerrahi açısından acil operasyon endikasyonu yoktu, hastaya ortopedi, üroloji, beyin cerrahi konsültasyonları önerildiği bilgilerine yer verildiği, üroloji uzmanı hastanın ortopedi veya genel cerrahi tarafindan eksplore edilirse sistostomi açık olarak konulabileceğinin önerildiği, saat $18: 30$ 'da da hastanın idrar durumunu öğrenmek için doktorun acil servise geldiği hususlarının yer aldığı, beyanlarına göre hastanın hem ortopedi uzmanı sanık doktor hem de ortopedi asistanı sanık doktor tarafindan muayene edilmesinden sonra düzenlenen konsültasyon notunda; bilinç açık oryante ve koopere, TA $11 / 60$, Nb 70, pelvik instabil, bilateral alt ekstremite motor muayene $(+)$, nörolojik defisit $(0)$, sol pubis inferior kenar ve sol asetabulum ön duvarda fraktür (+), olup ortopedik olarak hastaya cerrahi müdahale düşünülmediği, ortopedik cerrahi endikasyonu olmamakla beraber, bir buçuk ay yatak istirahatının uygun görüldüğü açıklamasının yapıldığı, doktor olarak görev yapan sanıkların ölen üzerinde gerçekleştirdikleri tetkik, teşhis ve tedaviye ilişkin uygulamalarının tıp kuralları bakımından değerlendirilmesine ilişkin olarak alınan çeşitli raporlarda sanıklarca yapılan işlemlerin ve verilen kararların etraflıca değerlendirmeye tabi tutulduğu, sonuç olarak sanıkların branşlarına ilişkin inceleme ve teşhis noktasında tıp kurallarına uygun hareket ettikleri, ancak genel beden travmasına maruz kalmış olan ölenin en az 24 saat müşahede altında tutulması gerekirken hastaneye başvurusundan 6-7 saat kadar sonra taburcu edilmesinin tıp kurallarına uygun olmadığı sonucuna varıldığı, otopsi raporları ile Adli Tıр Kurumu 1. Ihtisas Kurulu raporlarına göre ölümün "göğüs ve batın travmasına bağlı kot fraktürleri, pelvis fraktürü ve gelişen komplikasyonlar (akciğer embolisi) sonucu meydana gelmiş olduğunun" tespit edildiği, yine Adli Tıp Kurumu 1. Ihtisas Kurulu raporunda "ölüm nedeni olan akciğer embolisinin önceden öngörülecek ve engellenebilecek bir sebep olmadığı da tıbben bilindiğinden bu eksikliğin ölüme katkısı bulunmadığının mütalaa edildiği, bu itibarla alınan raporlarda bir eksikliğin bulunmadığı ve bu raporların sanıkların hukuki durumlarını tereddütsüz bir şekilde tespit etmeye elverişli oldukları anlaşıldığından eksik araştırmayla hüküm kurulmadığının kabulü gerekmektedir. Danıştay’ın ilgili dairesinin vermiş olduğu bu çoğunluk görüşüne katılmayan Genel Kurul Başkanı ve üç Genel Kurul Üyesi; "Ölenin genel beden travması sonucu gelişen akciğer embolisi nedeniyle öldüğü raporlarda bildirildiğine göre, sanıklar tarafından 24 saat müşahede altına alınmış olması halinde, emboli gelişmesinin önüne geçilip geçilemeyeceği veya emboliden sonra derhal teşhis ve müdahale edilerek ölüme engel olunup olunamayacağı hususunda rapor alınması gerektiği bu itibarla eksik araştırma ile hüküm 
kurulduğundan yerel mahkeme hükmünün öncelikle bu yönden bozulmasına karar verilmesi gerektiği" düşüncesiyle karşı oy kullanmışlardır. Eksik araştırma ile hüküm kurulmadığının kabul edilmesi nedeniyle sanıkların olayda görevlerinin gereklerini yapmada ihmal gösterip göstermedikleri, ihmal gösterdiklerinin kabulü halinde ise gerçeklesen ölüm neticesi ile eylemleri arasında nedensellik bağı bulunup bulunmadığı, buna bağlı olarak da eylemlerinin taksirle ölüme neden olma suçunu mu, yoksa TCK'nun 257/2. maddesi kapsamında görevi ihmal suçunu mu oluşturacağının belirlenmesine, doktor olarak görev yapan sanıkların, 24 saat müşahede altında tutmaları gerekirken 6-7 saat içinde taburcu etmeleri nedeniyle olayda görevlerinin gereklerini yapmakta ihmal gösterdikleri, ancak bu davranışları ile meydana gelen ölüm neticesi arasında nedensellik bağının bulunmadığı, başka bir anlatımla sanıklarının ihmali davranışlarının ölüme neden olacak nitelikte bulunmadığı, zira ölümün genel beden travması nedeniyle öngörülemeyecek ve engellenemeyecek biçimde ortaya çıkan akciğer embolisi komplikasyonu nedeniyle gerçekleştiğinin bilirkişi raporlarıyla kesin olarak belirlendiği, bu nedenle sanıkların ölüm sonucundan sorumlu tutulamayacakları, bununla birlikte genel beden travmasına maruz kalmış öleni erken taburcu etmek suretiyle görevlerinin gereklerini yerine getirmekte ihmal gösterdikleri, bu ihmal nedeniyle ölenin ölüm anına kadar yaşadığı çeşitli sıkıntılara maruz kalmasına diğer bir deyişle mağduriyetine sebep oldukları anlaşıldığından, sanıkların eylemlerinin TCK'nun 257/2. maddesi kapsaminda görevi ihmal suçunu oluşturduğu ve bu suçtan mahkûmiyetlerine karar verilmesi gerektiği gözetilmeden beraatlarına karar verilmesinde isabet bulunmamaktadır" denilmektedir (Yargıtay Ceza Genel Kurulu 09.12.2014 tarihli E: 2014/12-103, K: 2014/552 sayılı kararı).

\section{* * *}

Yargıtay'ın Ceza Dairesinin vermiş olduğu bir kararda dosya içeriği, Adli Tıp Kurumu 3. Adli Tıp İhtisas Kurulu'nun ve Yüksek Sağlık Şurası'nın raporlarına göre; 22.11.2005 tarihinde meydana gelen trafik kazası nedeni ile yaralanan katılanın, aynı gün getirildiği ... Hastanesinde Ortopedi ve Travmatoloji doktoru olan sanık tarafından muayenesi yapıldıktan sonra "sağ asetabulum, femur kırığı ve dolaşım bozukluğu tanısı" ile yatışının yapıldığı, ayağı alçıya alınan katılanın kalp damar uzmanının muayenesi sonrasında "alt ekstremite dolaşım bozukluğu" nedeni ile ... Hastanesine sevk edildiği ve buradaki tedavisi sırasında katılana sağ diz altı ampütasyonu yapıldığı, mevcut arter ve ven yırtığının fark edilmemiş olması, katılanın yeterince takibinin yapılmamış olması ve kalp damar cerrahi konsültasyonunun geç yapılması nedenleri ile sanık doktorun, mesleğinin gerektirdiği objektif özen ve dikkat yükümlülüğünü yerine getirmemek suretiyle katılanın yaralanmasına neden olduğu anlaşılmakla; sanığın sabit olan taksirle yaralama suçundan mahkûmiyetine karar verilmesi gerekirken; görevi kötüye kullanma suçundan hüküm kurulmasının kanuna aykırı olduğuna oybirliği ile karar verildi (Yargıtay 12. Ceza Dairesi 23.06.2014 tarihli E: 2014/28, K: 2014/15418 sayılı kararı).

Yargitay 13. Hukuk Dairesi 05.11.2014 tarihli E: 2014/8036, K: 2014/34353 sayılı kararında;

Davacı, 2010 yılının Ekim ayında sağ bacağında menüsküs ve kıkırdak bölümünde kireçlenme olduğundan ...Tıp Merkezi'ne başvurduğunu, Ortopedi ve Travmatoloji uzmanı olarak görev yapan doktorun bir takım tetkiklerin ardından sağ bacağından ameliyat olması gerektiğini söylediğini, ameliyat öncesinde davalı anestezi ve reanimasyon uzmanı doktorun belinden iğne vurarak sağ bacağını uyuşturmaya çalıştığını, operasyonu gerçekleştirecek olan davalı doktorun hastanın tepkime vermesi sebebiyle bacağın uyuşmadığını fark ettiğini, ikinci iğnenin yapıldığını, yine uyuşmadığı fark edilince tekrar iğne yapıldığını, son iğnenin ardından kendinden geçtiğini ve uyandığında servise indirilmiş olduğunu, aynı gece kendine geldiğinde sol elinden dirseğine kadar karıncalanma ve uyuşma olduğunu fark ettiğini, ameliyat sonrası olduğu için durumun normal olduğu belirtilerek ağıı kesici iğne yapıldığını ve ertesi gün taburcu edildiğini, 15 gün sonra kontrole gittiğinde sol kolundaki şikâyetin aynen devam ettiğini bildirdiğini, ancak önemli bir durumun bulunmadığı ve geçeceğinin söylendiğini, aralık ayında davalı doktordan tekrar randevu aldığını ve sorunun halen devam ettiğini, bunu aşırı şekilde hissettiğini belirttiğini, davalı tarafından EMG çekilmesi istenerek bir sorun olmadığının belirtildiğini ve nöroloji doktoruna sevk edildiğini, nöroloji bölümünde yapılan tetkiklerde sol elinin avuç içinde $10 \mathrm{~cm}$, dirseğinde ise $20 \mathrm{~cm}$ sinir sıkışması olduğu sonucuna ulaşıldığını, ardından davalı doktorun elinden ve kolundan olmak üzere iki yerinden cerrahi operasyon yapılması gerektiğini belirterek iki gün sonra ameliyata aldığını ve taburcu edildiğini, ertesi günü çok yüksek oranda ağrı ve sancı şikâyeti ile karşılaştı̆̆ını ve derhal aynı hastanenin acil servis bölümüne başvurduğunu, nöbetçi doktorun kolunun şiştiğini ve parmaklarının morardığını gözlemleyip hemen davalı doktora ulaşılması gerektiğini söylediğini, ancak kendisine ulaşılamayınca aynı hastanede görevli diğer ortopedi uzmanı tarafından elinin yarım alçıya alındığını, 15 gün sonra dikişlerin alındığını, elinin ve parmaklarının şiştiği fark edilince yapılan tetkiklerde halen sinir sıkışması bulunduğunun tespit edildiğini, nisan ayında tekrar davalı doktora başvurduğunda, tekrar bir cerrahi operasyon gerektiğini, önceki hatalı uygulama sebebiyle 
bu kez para alınmayacağını bildirerek kendi kusurunu ortaya koyduğunu, şikâyetlerinin aynen devam ettiğini, hiçbir düzelme olmadığını sağ bacağından ameliyat olmak için başvurduğu hastanede sol kolundan sakat kaldığını, bu duruma özensiz ve yanlış uygulamalar ile hatalı işlemlerin sebebiyet verdiğini, sol kolunda bariz bir fonksiyon kaybı bulunduğunu, ayrıca dış görünüş itibariyle de sakatlığın kolaylıkla tespit edilebildiğini, bu durumun ... Üniversitesi tarafından verilen sağlık kurulu raporu ile de belli olduğunu, maddi ve manevi olarak büyük zarar gördüğünü ileri sürerek, fazlası saklı kalmak üzere 1,000,00 TL maddi, 50,000, 00 TL manevi tazminatın olay tarihinden itibaren faiziyle tahsiline karar verilmesini istemiştir. Davalılar, davacının tedavisinde yapılması gereken her türlü tıbbi işlem ve müdahalenin yapıldığını, hiçbir kusurun bulunmadığını savunarak davanın reddini dilemiştir. Mahkemece, davanın reddine karar verilmiş; hüküm, davacı tarafından temyiz edilmiştir. Davacı, davalı hastanede görevli diğer davalı doktorlar tarafından sağ bacağında menüsküs ve kıkırdak bölümünde kireçlenme nedeniyle yapılan ameliyat sonrasında sol kolundan sakat kaldığını, hem bedensel hem de ruhsal olarak büyük üzüntü ve çöküş yaşadığını, ameliyatlardan sonra sol kolunda bariz bir fonksiyon kaybı bulunduğunu, ayrıca dış görünüş itibariyle de sakatlığın kolaylıkla tespit edilebildiğini ileri sürerek, maddi ve manevi zararının tahsili istemi ile eldeki davayı açmıştır. Somut olaya bakılacak olursa; davalı doktorların cerrahi müdahalede bulunduğu davacının iki kez ameliyat, tedavi ve müdahalelere maruz kaldığı anlaşılmaktadır. Adli Tıp Kurumu 2. Ihtisas Kurulu'nun 08.02.2013 tarihli raporuna göre;"... davacıya konulan tanılar, yapılan ameliyatlar ve uygulanan anestezi yöntemlerinin tıp kurallarına uygun olduğu, davacıda ameliyat sonrası oluştuğu iddia edilen sol kolda sinir sıkışması (kubital tünel ve karpal tünelde) ile spinal anestezi arasında illiyet bağı bulunmadığı ..." açıklanmış ise de, hükme esas alınan bu raporu hazırlayan heyette anestezi uzmanının bulunmadığı görülmektedir. $\mathrm{O}$ halde mahkemece, üniversiteden anestezi uzmanı öğretim üyesinin de bulunduğu konusunda üç kişilik bilirkişi kurulundan rapor alınarak, sonucuna göre bir karar vermelidir. Mahkemenin bu yönleri göz ardı ederek, eksik incelemeyle yazılı şekilde hüküm kurmuş olması usul ve yasaya aykırı olup bozmayı gerektirir.

$$
\text { * } \quad * \quad *
$$

Yargıtay Ceza Dairesi'nin bir diğer kararında mağdurun ağaçtan düşmesi sonucunda sol kolunun kırılması neticesinde ambulansla ... Devlet Hastanesi'ne götürüldüğ̈̈, ilk müdahalenin burada yapılmasından sonra icap nöbetçisi olan sanığın gelerek kolu alçıya aldığı, mağduru hastaneye yatırdığı, hastanede yattığı sırada pazar günü öğleden sonra elde morarma olduğu, koldan kötü koku geldiği, pazartesi günü sabah ameliyata alınarak kırığa tel konulduğu, aynı gün öğleden sonra ise elde morarmanın artması üzerine tekrar ameliyata alınarak fasyotomi yapıldığı, devamında ertesi sabah ...Üniversitesi Hastanesi'ne sevk edildiği, burada tedavisine devam edildiği ancak kolunun kurtarılamayarak organ işlevinin yitirilmesine neden olunması şeklindeki olayda, Adli Tıp Kurumu'nun raporunda açık kırı̆ıın tabii bir komplikasyonu olarak gazlı gangren meydana gelebileceği enderde olsa bilindiğinden ilk müdahale eden ortopedi uzmanının sanata uygun olarak açık yaraya müdahale edip eksizyon sütürünü hastayı görür görmez yapması ve ondan sonra takip altına alması gerektiği, ayrıca ampirik olarak tek başına hastaya verilen antibiyotiğin açık kırıktaki yaralanmaların proflaksisinde kullanımı uygun olmayıp antiaerobik etkisi bulunmadığı da dikkate alındığında, sanığın uygulamalarının tıp kurallarına uygun olmadı̆̆ına oy birliğiyle karar verilmiş, Yüksek Sağlık Şurası'nın raporunda da mağdurun ön kol kırığına ilk müdahalede alçı ve yara bakımı yapılmasının uygun olduğu, ancak devamında dolaşım kontrolü, alçının kama şeklinde açılmasında gecikilmesi, yara bakımı ve kontrolü ile gelişen enfeksiyonun tespitinde geç kalınması ve anaerob enfeksiyonlarda ilk tercih edilen penisilin ve klindamisin seçilmeyerek uygun olmayan antibiyotik tedavisi verilmesi neticesi oluşan uzuv kaybında sanığın kusurlu olduğunun belirlenmesi karşısında sanığa taksirle yaralama suçundan mahkûmiyet kararı verilmesine 06.11.2014 tarihinde oybirliğiyle karar verildi. (Yargıtay 12. Ceza Dairesi 06.11.2014 tarihli E: 2014/10845, K: 2014/22094)

* * *

Katılanın 04.07.2006 tarihinde cam kesiği nedeniyle sanıkların nöbetçi ortopedi asistanı olarak çalışmakta olduğu hastaneye başvurduğu, burada yarasının pansuman edilerek elindeki kesiğe dikiş atılıp gönderildiği, mağdurun çeşitli yerlerde pansuman yaptırdıktan sonra... Polikliniğinde dikişlerini aldırdığı, dikişleri aldırmasından sonra dahi ağrılarının geçmemesi ve 5. parmakta his kaybı olması nedeniyle aynı polikliniğe başvurarak elinin grafilerini çektirdiği, doktorun elinde cam kırığının kaldığını söylemesi üzerine... Tıp Merkezinde elinden $2 \times 3,5 \mathrm{~cm}$ ebatlarında 1,5 mm kalınlığında cam parçasının çıkarıldığı, dosya içinde bulunan sağlık raporuna göre, bu kırık cam parçası nedeniyle sol elde ulnar sinir alanında yüzeyel duyu kusuru saptandığı, sol el 4. ve 5. parmakta abdüksiyon ve addüksiyon 4/5 düzeyinde olduğu, yapılan EMG de solda lezyon düzeyi altında ulnar sinirin hafif parsiyel aksonal dejenerasyonu saptandığı, etkilenmenin bilek düzeyindeki kesiden ya da eldeki yabancı cisimden mi kaynaklandığının kesin olarak ayırt edilemeyeceği, EMG'de rejenerasyon bulgularının 
olması nedeniyle üç ay sonra kontrol muayenesi gerektiği, Yüksek Sağlık Şurası'ndan alınan raporda ise; eldeki kesi nedeniyle başvuran hastada grafi alınması gerekirken grafi almadan girişimde bulunulmasının tıbbi bir eksiklik olduğu, ancak kesi içerisindeki cam parçasının ebatlarının büyüklüğü dikkate alındığında, fiziki muayene ile de tespit edilebileceği ve hastanın kendisi tarafından da fark edilebileceği halde, olaydan sonra üç ay boyunca hastanın herhangi bir sağlık kuruluşuna başvurmamış olmasının düşünülemeyeceği ve olayı şüpheli hale getirdiğinin belirtilmesi gerektiğinin bildirilmesine göre, eylemin görevi ihmal olarak nitelendirilmesinde bir isabetsizlik bulunmadığı anlaşılmakla yapılan sanığın eyleminin görevi ihmal olarak değerlendirilmesine karar verilmiş. Karara muhalefet şerhi olarak da sanığın beraatine yönelik bozma sebebine katılmakla birlikte sanığın eyleminin taksirle yaralama yerine görevi ihmal olarak değerlendiren sayın çoğunluğun görüşüne katılınmadığı, dosya kapsamı ve mahkemenin kabulüne göre "Eldeki kesi nedeniyle acil servise başvuran mağdurda grafi alınması gerekirken grafi alınmadan girişimde bulunulmasının tıbbi bir eksiklik olduğu, ancak kesi içerisindeki cam parçasının ebatlarının büyüklüğü dikkate alındığında, fiziki muayene ile de tespit edilebileceği ve hastanın kendisi tarafından da fark edilebileceği” şeklindeki kabulü, eylemin taksirle işlendiğini göstermektedir. Sanık doktor Ortopedi ve Travmatoloji asistanıdır. Hastanede nöbetçi olduğu acil serviste mağdur hasta ile ilgilenmiş ve tedavisini yapmıştır. Ancak bu tedavi sırasında gerekli dikkat ve özeni göstermeyerek hastanın elinde cam parçasının kalmasına neden olmuştur. Sanığın eylemi 765 sayılı Kanunda "Tedbirsizlik veya dikkatsizlik veya meslek ve sanatta acemilik" ve 5237 sayılı Kanunda ise "dikkat ve özen yükümlülüğüne aykırılık" olarak gösterilen taksirdir. Sanık biraz daha dikkatli ve özenli olsaydı belki cam parçası mağdurun elinde kalmamış olacaktı. Adli Tıp Kurumu'ndan rapor alınarak sanığın taksirli davranışı sonucu oluşan yaralama arasındaki illiyet bağının olup olmadığının tespit edilmesi gerekir. Eğer cam parçasının unutulması sonucu etkili olmamışsa sanığın taksirli hareketi ile oluşan netice arasında illiyet bağı kurulamayacak olduğundan sanık hakkında beraat kararı verilecektir. Hastane acil servislerinin nasıl bir yoğunlukta olduğu ve burada görev yapan personelin fedakârlıkları ile işlerin yürütüldü̈̆̈̈̈ de nazara alınarak bir değerlendirme yapılması gerekir. En son düşünülebilecek olan görevi kötüye kullanma olarak değerlendirilebilecek bir hareketi dosyaya yansımayan sanığın görevi kötüye kullanma suçundan da cezalandırılmaması gerekir. Yukarıda açıkladığımız ve mahalli mahkemece nazara alınacak olguyu düşündüğümüz bu gerekçelerle sayın çoğunluğun sanık hakkındaki suç vasıflarına yönelik görüşlerine katılmıyoruz. (Yargıtay 12. Ceza Dairesi 14.01.2015 tarihli E: 2014/18700, K: 2015/319 sayılı kararı). Söz konusu kararda muhalefet şerhi burada oldukça dikkat çekici özelliktedir. Hastanedeki yoğunlukların da göz önünde bulundurulması gerektiğinin şerh olarak düşülmesi önem arz etmektedir.

Yargitay 12. Ceza Dairesi'nin 13.06.2019 tarihli E: 2017/11226, K: 2019/7286 kararında;

Katılanın iş yerinde çalışırken geçirdiği kaza sonucu sol kolunun kırılması üzerine ...Hastanesi'ne kaldırıldığı, burada ortopedi uzmanı olan sanık doktor tarafindan humerus şaft kırığı tespit edilerek ameliyat edildiği, üç gün sonra kolda ağrı mevcut olduğu halde hastanın taburcu edildiği, şikâyetleri geçmediği için tekrar aynı hastaneye müracaat eden hastaya doktorun EMG tetkiki yaptığı, hastayı fizik tedaviye yönlendirdiği, şikâyetleri geçmeyen hastanın daha sonra başka bir hastaneye giderek yatırıldığı ve üst kol düzeyinde radial sinir yaralanması tanısıyla ameliyat edildiği, bu ameliyatta tespit edilen sinir hasarının sanık tarafından yapılan ilk ameliyatta meydana geldiğinin iddia edildiği olayda; Yüksek Sağlık Şurası'nın raporunda; doktorun yaptığı ameliyat sonrası ortaya çıkan sinir kesisine bağIı tablonun ameliyatın beklenen bir komplikasyonu olduğunu, ancak bu komplikasyonun takip ve tedavisinde doktorun özensiz davrandığının ve dolayısıyla kusurlu olduğunun belirtildiği; bilirkişi raporunda tıbben gerekenlerin yapıldığı ve tedavide gecikme söz konusu olmadığı belirtilmiş ise de, Adli Tıp 2. İhtisas Kurulu'nun ve sonrasında alınan Adli Tıp Genel Kurulu'nun raporlarında benzer şekilde; humerus şaft kırıklarında radial sinir felcinin \%6-15 oranlarında görülebildiği, bu olguların birçoğunda sinir hasarının yaralanma anında oluştuğu, daha az oranda da tedavinin devamı esnasında sonradan geliştiğinin tıbben bilindiği, kişide çalıştığı işyerinde geçirdiği kaza sonucu sol humerus şaft kırığı oluştuğu, ameliyata alındığı ve kırığın intramedüler çivi ile redükte edildiği, ameliyat sonrası takiplerinde kişide radial sinir hasarı oluştuğunun tıbbi belgelerde kayıtlı olduğu, yine tıbbi belgelerde ameliyat öncesi yapılan muayenesinde parsiyel radial sinir hasarını düşündüren bulguların bulunduğunun kayıtlı olduğu, fakat radial sinir paralizisi ifadesinin veya tanısının geçmediği bu tür kırıklarda ortopedi literatüründe altın standart olarak kabul edilen açık redüksiyon ve plak fiksasyon yerine intramedüller çivi uygulamasının cerrahın tercihinde olduğu, ancak ameliyat esnasında radial sinir hasarının nedeninin ortaya konulması için sinir eksplorasyonu yapılmamasının ve ameliyat sonrasında ise radial sinir paralizi bulgularının artmasına rağmen sinir eksplorasyon yapılmamasının tıp biliminin genel kabul görmüş ilke ve kurallarına uygun olmadığı görüşlerine yer verilmiş olması, söz konusu raporların 
dosya kapsamı ve maddi vakıa ile uyumlu olması karşısında, sanığın tıp kurallarına aykırı işlemde bulunarak katılanın yaralanmasına sebebiyet verdiği ve bu suretle kusurlu olduğu anlaşılmakla; yapılan yargılamaya, toplanıp karar yerinde gösterilen delillere, mahkemenin kovuşturma sonuçlarına uygun olarak oluşan kanaat ve takdirine, incelenen dosya kapsamına göre, sanık ve sanık müdafinin yerinde görülmeyen sair temyiz itirazlarının reddine, sair yönleri usul ve kanuna uygun bulunan hükmün düzeltilerek onanmasına oy birliğiyle karar verildi.

Yargıtay 12. Ceza Dairesi 09.04.2019 tarihli E: 2017/6800, K: 2019/4748 ölenin yüksekten düştüğü, ... Hastanesine kaldırıldığı, acil serviste nöbetçi hekim olan doktor tarafindan ilk muayenesinin yapıldığı, çekilen grafilerinde nöbetçi hekim tarafindan sol ön kol açık kırı̆̆ı ve sol femur kırığı görüldüğünden, acil servis hekiminin nöbetçi ortopedi uzmanı olan sanık doktoru telefon ile bilgilendirdiği, ancak sanı̆̆ın hastaneye gelemeyeceğini, hastanın bir üst merkeze sevk edilmesini söylediği, bunun üzerine hastanın bir ambulansla ... Hastanesine sevk edildiği, hastanın yanında yakınları olmadığı için hastanenin röntgen teknisyeninin kendisine refakatçi olarak verildiği, ... Hastanesi'nin ise belgelerinde, otomasyon sisteminde, acil polis defterinde, hastanın kaydına rastlanmadığı, ilk başvurduğu hastaneye geri getirilen ölenin tekrar müşahede odasına alındığı, acil nöbetçi hekimi tarafından yeniden ortopedi uzmanı olan sanı̆̆ın telefon ile bilgilendirildiği, onun da hastanın acil müşahede odasında tutulması gerektiğini belirterek hastaneye ancak sabahleyin geleceğini söylediği, müşahede odasında tansiyon ve vital bulgu takibi yapılırken durumu kötüleşen hastanın sabahleyin hayatını kaybettiği olayda; Adli Tıp Kurumu 1. İhtisas Dairesi ve Yüksek Sağlık Şurası tarafından düzenlenen raporlarda pelvis ve femur kırı̆̆ olan ölenin muayenesi için ortopedi konsültasyonu istenmesine rağmen ortopedi icapçı uzmanı olan sanığın hastayı muayene etmek için hastaneye gelmemesinin eksiklik olduğu hususunda, görüş birliğine varılarak, meydana gelen olayda sanığın kusurlu hareket ettiğini kabulde zorunluluk bulunmakla birlikte, sanığın eylemi ile netice arasında illiyet bağının kesin bir şekilde kurulamadığı, bu nedenle sanığın taksirle öldürme suçundan sorumlu tutulamayacağı, ancak bahsedilen raporlar ve tüm dosya kapsamından sanı̆ıın üzerine düşen görevleri yerine getirmediği ve eyleminin, 5237 sayılı TCK'nın 257/2 maddesi kapsamında "görevinin gereklerini yapmakta ihmal veya gecikme gösterme" fiili olarak ortaya çıktığı anlaşımakla; sanık müdafinin zaman aşımına yönelik temyiz itirazları bu itibarla yerinde görülmüş olup, hükmün gerçekleşen zamanaşımı nedeniyle 5320 sayılı Kanunun 8/1. maddesi gereğince halen uygulanmakta olan 1412 sayılı CMUK'un (Ceza Muhakemeleri Usulü Kanunu) 321. maddesi uyarınca bozulmasına, aynı kanunun 322. maddesinin verdiği yetkiye dayanılarak 5237 sayılı TCK'nın 66/1-e ve 5271 sayılı CMK'nın (Ceza Muhakemesi Kanunu) 223/8. maddeleri gereğince sanık hakkındaki kamu davasının düşmesine oy birliğiyle karar verildi.

... Hastanesinde ortopedi uzmanı olarak görev yapan sanığın, katılanın kolundaki rahatsızlığın tedavisiyle ilgilendiği ancak yaptığı operasyon ve tedavi yöntemleri nedeniyle katılanın sağ kolunda uzuv zaafı oluşmasına neden olduğu iddiasıyla görevi kötüye kullanma ve taksirle yaralama suçlarından hakkında açılan kamu davasında, Adli Tıp Kurumu Başkanlığı 2. Ihtisas Kurulu'nun raporuna göre, yapılan ameliyatın niteliği ve ameliyat bölgesinin özelliği nedeniyle sinir lezyonları oluşabileceği ve bu durumun ameliyatın komplikasyonu olarak nitelendirildiği, ancak ameliyat sonrası yapılan tıbbi kontrollerde ulnar sinir kesisinin fark edilerek tedaviye zaman geçirilmeden başlanması gerektiği, tedavinin zamanında yapılması halinde kesiye bağı ortaya çıkan hasarın daha hafif olabileceği, sanık hekimin ameliyattan sonraki komplikasyon yönetiminde eksiklik olduğu ve bu yönden kusurlu olduğu tespit edildiğinden eyleminin kül halinde görevi kötüye kullanma suçunu oluşturduğu anlaşılmakla, suç vasfından dolayı beraat kararı verilemeyeceği gözetilmeden aynı eylem nedeniyle görevi kötüye kullanma suçundan beraat, taksirle yaralama suçundan da hüküm açıklanmasının geri bırakılmasına karar verilerek çelişkiye yol açılmasından dolayı bozulmasına oy birliğiyle karar verildi. (Yargıtay 5. Ceza Dairesi 29.01.2019 tarihli E: 2017/997, K: 2019/919 sayılı kararı)

Yargitay 12. Ceza Dairesi 29.11.2018 tarihli E: 2017/3368, K: 2018/11418 sayılı kararında;

Ölenin yüksekten düşme nedeniyle ... Hastanesi'ne ambulansla getirildiği, PA Akciğer grafisi, AP pelvis grafisi, iki yönlü servikal grafi istendiği, hasta adına düzenlenen adli muayene raporunda; "bilinci açık, koopere ve oryante, şahsın sağ bacağında hareket kısıtlılığı gözlendiği, çekilen pelvis grafisi net olmamakla beraber simfisis pubiste ayrışma olduğunun gözlendiği, şahsın pelvis kırığı ön tanısı ile... Devlet Hastanesi Acil Polikliniğine sevkinin uygun görüldüğü" belirtilerek sevk edildiği, acil hekimi tarafından çağırılan ortopedi uzmanı sanık doktorun hastayı ilk değerlendirmesinde sol kalça hareketlerinin ağrılı olduğunun, BT istendiği, röntgenin normal olduğunun; ikinci değerlendirmesinde; normal muayene, X-Ray ve BBT normal olduğunun belirtildiği, hasta adına düzenlenen adli muayene 
raporlarında herhangi bir patolojiye rastlanmadığı belirtilerek hastanın aynı gün eksterne edildiği, hastanın evinde fenalaşması üzerine... Devlet Hastanesi'ne 112 acil ekibi tarafından getirildiği, nabız ve KTA(Kalp tepe atımı) alınamadığı CPR'a (Kardiyopulmoner Resüsitasyon) cevap verilememesi üzerine eksitus kabul edildiği; Adli Tıp Kurumu 1. İhtisas Kurulu raporunda; zamanında otopsi yapılarak iç organ değişimleri araştırılmamış olmakla birlikte tıbbi belgelerdeki bulgular, grafi bulguları ve olayın gelişimi birlikte değerlendirildiğinde, kişinin ölümünün L5 ve sakrum kırıklarından gelişen komplikasyonlar sonucu meydana geldiği görüşüne yer verildiği; Adli Tıp Kurumu 3. İhtisas Kurulu raporunda; kişinin sevk edildiği... Hastanesi'nde yapılan ortopedi konsültasyonunda çekilen pelvis AP grafisinde ve pelvik tomografide patoloji bulunmadığı kayıtlı ise de, aynı grafilerin tetkikinde, parçalı sakrum kırı̆̆ı L5 vertebrada 3 kolon kırığı ile sağ sakroiliak eklemde ayrılma görüldüğü, bu lezyonları bulunan kişinin hastaneye yatırılarak müşahede altında tutulması ve yakından takip edilmesi gerektiği, bunların yapılmamasının eksiklik olup tıp kurallarına uygun olmadığı görüşünün belirtildiği; yine Yüksek Sağlık Şurası'nın raporunda; ... Devlet Hastanesi acil servisinde yüksekten düşme şikâyeti olan hastaya göğüs travması yönünden değerlendirilmesi için genel cerrahi ve göğüs cerrahisi konsültasyonlarının istenmemesinin eksiklik olduğu, konsültasyona gelen ortopedi uzmanı doktorun hastanın fizik muayenesini tam yapmayarak özensiz davrandığı, grafilerde de vertebra ve parçalı sakrum kırığının atlanmış olduğu dikkate alındığında grafilerin iyi değerlendirilmemiş olduğu anlaşılmakta doktorun kusurlu olduğunun belirtildiği anlaşılmakla yapılan incelemede; yapılan yargılamaya, toplanıp karar yerinde gösterilen delillere, mahkemenin kovuşturma sonuçlarına uygun olarak oluşan kanaat ve takdirine, incelenen dosya kapsamına göre, sanık müdafinin yerinde görülmeyen sair temyiz itirazlarının reddine; ancak; sonuç olarak iki yıl hapis cezasına mahkûm edilen ve bu cezası ertelenen sanık hakkında TCK'nın 51/7 maddesi uyarınca denetim süresi içinde sanığın kasıtlı bir suç işlemesi halinde cezanın kısmen veya tamamen infazına karar verileceği ihtarına, yerel mahkemenin kararının düzeltilerek onanmasına oy birliği ile karar verilmiş.

Yargıtay 12. Ceza Dairesi 27.09.2018 tarihli E: 2018/5197, K: 2018/8786 sayılı kararında;

Trafik kazası nedeniyle... Hastanesi'ne başvuran katılanın, ortopedi asistanı sanık doktor tarafindan muayene edilerek sağ bacağının atele alındığı, yaklaşık 15 gün sonra katılanın sol bacağındaki dinmeyen ağrılar nedeniyle... . Hastanesi'ne başvurduğu, burada yapılan tetkikler sonucu katılanın sol bacağının kırık olduğunun tespit edildiği olayda, Adli Tıp Kurumu 2. Ihtisas Dairesi'nin raporunda...Hastanesi'nin genel adli muayene formunda belirtildiği üzere ortopedi uzmanının hastaya gerekli muayeneyi yapıp gerekli grafiyi istediğinin anlaşıldığı, çoklu yaralanmaları olan hastaların muayenesinin ve ayrılmamış olan kırıklarının klinik muayene ile ayrımının yapılmasının zor olduğu, rutin röntgen çekimlerinde belli bir tarafa konan sağ ve solu belirtir işaretin çekilen iki adet bacak grafisinde ters konulduğunun, bunun da ortopedi uzmanını yanlış yönlendirdiğinin anlaşıldığı, mevcut bulgularla ortopedi uzmanının kırığın sağ veya sol ayrımını klinik bulgular ile yapmasının tıbben beklenmediği, dolayısıyla bu yönden atfı kabil kusuru bulunmadığı; grafiyi çeken radyoloji teknisyeninin grafi taraf işaretlemesini doğru yapmamasının eksiklik olduğu, ancak hasta sayısının çok fazla olduğu hastanelerde acil şartlarda çekilen grafilerde

yoğunluğa bağlı taraf işareti hatalarının görülebildiği, kısa sürede fark edilip şahsa gereken tedavinin yapıldığı, gecikmenin sonuca katkısının olmadığı oy birliği ile mütalaa olunduğu"belirtilmiş ise de; katılanı ilk muayene eden olay günü acil nöbetçi doktoru tarafindan düzenlenen genel adli muayene raporunda, "katılanın sol diz lateralde abrazyon, gövde ön yüz tarafinda yaygın abrazyonların mevcut, sol 8. kot hizasında lateralde ekimoz, sağ dirsekte ekimoz, şuurunun açık, sağ fibula başı kırık, sakrum ve pubiste kırık"olduğunun belirtildiği, sanık doktor tarafindan olay günü düzenlenen genel adli muayene raporunda, katılanın bilincinin açık olduğu, çekilen $x$-ray grafilerinde sağ fibula başı kırığı ve sol sakrum ve pubiste fraktür tespit edildiğinin, sağ fibula kırığına yönelik uzun bacak atel uygulandığının, hastanın sakrum kırığına yönelik ise hemogram takibi önerildiğinin belirtilmesi ile sanığın aşamalarda verdiği benzer beyanlarında da sol pubis kemiği kırığının cerrahi müdahaleyi gerektirecek bir kırık olmadığını bu sebeple cerrahi müdahale planlanmadığını ifade etmesi karşısında, ortopedi asistanı sanık doktorun görevinin gereklerini yerine getirmek hususunda ihmalinin bulunduğu gözetilerek, yapılan yargılamaya, toplanıp karar yerinde gösterilen delillere, mahkemenin kovuşturma sonuçlarına uygun olarak oluşan kanaat ve takdirine, incelenen dosya kapsamına göre, sanık müdafinin, mahkûmiyet kararının kanuna aykırı olduğuna, katılan vekilinin, olayda TCK'nın 257/1 maddesi koşullarının oluştuğuna ilişkin temyiz isteminin reddine, ancak; sanık hakkında tayin edilen hapis cezası adli para cezasına çevrilmesi esnasında uygulanan kanun maddesinin gösterilmemesi suretiyle CMK'nın 232/6 maddesine aykırı davranılması, kanuna aykırı olup, sanık müdafinin temyiz itirazları bu itibarla yerinde görüldüğünden, hükmün bozulmasına; yasaya uygun bulunan hükmün 
isteme aykırı olarak düzeltilerek onanmasına oy birliği ile karar verildi.

Yargitay 12. Ceza Dairesi 12.06.2018 tarihli E: 2016/8142, K: 2018/6663 sayılı kararında;

Olay günü iş kazası sonucu mermer bloğun üzerine düşmesi nedeni ile yaralanan çalışanın kaldıııldığı ... Hastanesi'nde ortopedi uzmanı olarak görev yapan sanık tarafından müdahale edildiği, bilahare ilk olarak buradan genel cerrahi konsültasyonu için ... Hastanesi'ne, buradan da ... Eğitim ve Araştırma Hastanesi'ne sevk edildiği, yolda genel beden travmasına bağlı sağ femur kırığı ile karakterli büyük damar (sağ femoral arter ve sağ femoral ven) yaralanmalarından gelişen iç kanama sonucu öldüğü anlaşılan olayda; Adli Tıp Kurumu 1. Ihtisas Dairesi'nin raporuna göre, genel beden travması sonucu femur kırığı nedeni ile götürüldüğü ...Devlet Hastanesi'nde, genel cerrahi ve kalp damar cerrahi konsültasyonları istenmeden ve hasta stabil hale getirilmeden sevk edilmesinin tıp kurallarına uygun olmadığının belirlendiği, sanığın bu eylemi ile ölüm arasında uygun illiyet bağııı bulunup bulunmadığı tespit edilemese de, sanığın ihmal göstererek görevinin gereklerini usulüne uygun bir şekilde yapmadığının sabit olduğu cihetle, sanığın eyleminin ihmal sureti ile görevi kötüye kullanmak suçunu oluşturduğunun kabulü ve TCK'nın 257/2. maddesi uyarınca cezalandırılmasına karar verilmesi gerekirken, eylemin TCK'nın 257/1. maddesinde belirtilen görevi kötüye kullanmak suçunu oluşturduğunun kabulü ile sanığın mahkûmiyetine karar verilmesi, sanık hakkında hükmolunan hapis cezasının adli para cezasına çevrildiği aşamada bir gün karşıı̆ı̆ miktarın belirlenmesine ilişkin uygulama maddesinin gösterilmemesi sureti ile CMK'nın 232/6. maddesine aykırı davranılması, kanuna aykırı olup, sanık müdafiinin temyiz itirazları bu nedenle yerinde görüldügünnden, hükmün 5320 sayllı Kanunun 8. maddesi gereğince halen uygulanmakta olan 1412 sayılı CMUK'un 321. maddesi gereğince isteme uygun olarak bozulmasına oy birliğiyle karar verildi.

Davacı, 2000 yılında geçirdiği trafik kazası sonucu sol kolunu kaybettiğinden yaklaşık 12 yıldır yaşamını sağ eli ile sürdürdüğünü, davalının sahibi olduğu dükkânda sağ el işaret parmağından yaralandığını, ... Hastanesi'nde yanlış tedavi edildiğini ve parmağında kalıcı hasar meydana geldiğini, birleşen davada ise davalı hastanede davalı doktorlar tarafindan uygulanan yanlış tedavi nedeni ile parmağını hareket ettiremediğini ileri sürerek ve fazlaya ilişkin hakları saklı kalmak kaydı ile 2,000,00 TL maddi ve 100,000,00 TL manevi tazminatın davalılardan ortaklaşa ve zincirleme olarak tahsilini istemiştir. Mahkemece, asıl ve birleşen davanın reddine karar verilmiş; hüküm, davacı tarafından temyiz edilmiştir.

Mahkemece, alınan bilirkişi raporlarının birbirini teyit ettiği, yapılan tedavinin tıp kurallarına uygun olduğunun ve hekimlere kusur atfedilemeyeceğinin tespit edildiği gerekçesi ile ret kararı verilmiştir. ... Üniversitesi'nden alınan bilirkişi heyet raporunda acilde görevli doktor davalı tarafından davacı yeterli muayene edilmiş olsa idi, hastadaki tendon kesisinin fark edileceği; hastanın beş gün sonra aynı hastanedeki ortopedi polikliniğinde davalı doktor tarafından yeterli muayene yapılmadığı için tendon kesisinin tespit edilemediği, her iki doktorun da yeterli muayene yapmadığından tendon kesisini saptayamadıkları yönünde görüş bildirilmiştir. Buna karşın alınan Adli Tıp raporunda tedavi seyrinin tıp kurallarına uygun olduğu, hekimlere kusur atfedilemeyeceği bildirilmiş olup, dosyada mevcut iki rapor arasında çelişki oluşmuştur. Mahkemece, gerekçede hangi rapora üstünlük tanındığı açıklanmamış, raporlar birbirini teyit etmediği halde teyit ettiği kabul edilerek hüküm kurulmuştur. Mahkemece, birleşen davada alınan bilirkişi raporları arasında çelişki oluştuğu gözetilerek ve çelişkinin giderilmesi amacı ile uzman bilirkişiden rapor alınarak hasıl olacak sonuca göre bir karar verilmesi gerekirken, eksik inceleme ile yazılı şekilde karar verilmesi usul ve yasaya aykırı olup, bozmayı gerektirir (Yargıtay 13. Hukuk Dairesi 10.05.2018 tarihli E: 2015/28490, K: 2018/5701).

Yargitay 13. Hukuk Dairesi 09.05.2018 tarihli E: 2015/40782, K: 2018/5451 sayılı kararında davacı, davalı şirketin işlettiği hastanede, davalı şirket doktorları tarafindan bel fitığı ameliyatı olduğunu ve taburcu edildiğini, ameliyattan iki hafta sonra başlayan şiddetli ağrı sebebi ile hemen kendisini ameliyat eden doktora başvurduğunu, şiddetli ağrıları olduğunu, yapılan tetkiklerde şikayetlerinin nedeninin bir türlü bulunamadığını ve yaklaşık altı ay boyunca böyle devam ettiğini, bu sırada davalı şirket hastanesinde görevli ortopedi doktoru tarafından rahatsızlıklarından dolayı kalça eklemlerinde kireçlenme olabileceği düşüncesi ile her iki kalçasından iğneler yapıldığını, bu süreçten sonra ağrıların nedeni olarak enfeksiyon teşhisi konulduğunu ve enfeksiyon tedavisine başlandığını, uzun süren ilaç tedavisinden sonuç alınamadığını malulen emekli olduğunu, çalışma gücünü kaybettiğini ve maddi zarara uğradığını ileri sürerek fazlaya ilişkin hakları sakı kalmak kaydıyla çektiği elem ve acılar için 50,000,00 TL manevi tazminatın ameliyat tarihinden itibaren, iş gücü kaybı nedeniyle uğradığı 15,000,00 TL maddi zarar için emekliye ayrıldığı tarihten itibaren işleyecek yasal faizi ile birlikte davalılardan müştereken ve müteselsilen tahsiline karar verilmesini talep etmiştir. Davalılar, yapılan işlemde hekime 
yüklenebilecek kusur olmadığını savunarak davanın reddini dilemiştir. Mahkemece davanın reddine karar verilmiş; hüküm, davacı tarafından temyiz edilmiştir. Mahkemece alınan Adli Tıp Kurumu raporunda; semptomatik bel fitığının tedavisinde cerrahinin kullanılabileceği, diskitisin, disk aralığının enfeksiyonu olduğu, primer olarak çocukluk çağında diskin kanlanma özelliklerine bağlı görüldüğü, erişkin yaşta daha çok diskektomi sonrası gelişen enfeksiyon olarak ortaya çıktı ı̆ı, bazı risk faktörleri taşıyan hastalarda kendiliğinden de gelişebileceği, kişinin bel fitığı tanısı ile... Hastanesi'nde ameliyata alındığı, sağ L4-5 diskektomi yapıldığı, ameliyat sonrası takiplerinde diskitis geliştiğinin tıbbi belgelerden anlaşıldığı, kişinin... Hastanesi'nde yapılan bel fitığı ameliyatı sonrası ortaya çıkan durumun bu tür ameliyatlardan sonra her türlü özene rağmen oluşabilen herhangi bir tıbbi kusur ya da ihmal izafe edilemeyen "komplikasyon" olarak nitelendirildiği ve ameliyatı gerçekleştiren sağlık çalışanlarına atfı kabil kusur bulunmadığı belirlenmiş, mahkemece bu rapor esas alınarak davanın reddine karar verilmiştir. Somut olaya bakılacak olursa; mahkemece Adli Tıp Kurumu raporu esas alınarak hüküm verilmiş ise de raporda enfeksiyonun yarada mı omurgada mı oluştuğunun belirlenmediği, hastanenin gerekli hijyen koşullarına sahip olup olmadığının değerlendirilmediği, hastada oluşan enfeksiyonun zamanında teşhis edilip edilmediği, edildi ise gerekli tedaviye derhal başlanıp başlanmadığı hususlarında yeterli açıklamayı içermediği anlaşılmaktadır. O halde mahkemece bilirkişi kurulundan, özellikle enfeksiyonun nerede oluştuğu, bu oluşumda hastanenin hijyen koşullarına dikkat edip etmediği, oluşan enfeksiyonun zamanında teşhis edilerek doğru tedaviye başlanıp başlanmadı ̆̆ hususları nazara alınarak davalı doktora yüklenebilecek atfı kabil bir kusur olup olmadığı hususlarında, nedenlerini açıklayıcı, davacı tarafın itirazlarını karşılayacak mahiyette, mahkeme ve Yargıtay denetimine elverişli rapor alınarak, davalıların kusurlu olup olmadığının belirlenmesi, sonucuna göre karar verilmesi gerekirken, bu yön göz ardı edilerek, eksik incelemeye dayanılarak, yazılı şekilde hüküm kurulmuş olması usul ve yasaya aykırı olup bozmayı gerektirir.

\section{* * *}

Yargıtay 11. Ceza Dairesi 25.12.2017 tarihli E: 2017/2560, K: 2017/9305 sayılı kararında sanık hakkında taksirle yaralama suçundan kurulan beraat hükmüne yönelik katılan vekilinin ve Cumhuriyet Savcısının temyiz itirazlarının incelenmesinde ise; ... Hastanesi'nde Ortopedi ve Travmatoloji uzmanı olan sanığın "girişimsel artroskopi" ameliyatı yaptığı sırada gereken dikkat ve özeni göstermemesi nedeniyle katılanın damarlarının yaralanmasına sebep olduğunun, ameliyattan sonra katılanın sol bacağında şişme ve ağıı gibi bir takım komplikasyonlar gelişmesine rağmen gerekli tedbirleri almadığının, katılanın ameliyattan uzunca bir süre sonra bir başka merkeze sevkini yaptığının, bu şekilde ameliyat sırasında ve sonrasında özensiz, dikkatsiz ve kayıtsız davranışları ile katılanın sol ayağının kesilmesine sebep olmak suretiyle üzerine atılı taksirle yaralama suçunun işlendiğinin iddia olunduğu somut olayda; sanık üzerine atılı suçu kabul etmemiş ise de; katılanın ameliyatından sonra turnike uygulamasına bağlı damar yapısında hasar olup olmadığını ameliyat bitiminde kontrol etmesi gerektiği, bu yönde vasküler yapılar açısından damar yapısının fonksiyonunun normal olduğuna dair herhangi bir tıbbi kaydın bulunamaması, dosya içerisinde mevcut raporlardan ilk 4-6 saatlik dönemin akut bir arteriyal yaralanmada veya dolaşım bozukluğunda tekrar kanlanmayı sağlayıp, etkilenen uzvu kurtarmak için müdahalenin yapılmasının gerekli olduğunun ve bu sürenin "altın zaman" olduğunun anlaşıması; sanı̆̆ın, katılanı yakın olan ...Tıp Fakültesi'ne sevki gerekirken uzak olan ... . Tıp Fakültesi'ne sevk ederek bu sevk sırasında da zaman kaybına neden olduğunun belirlenmesi karşısında; gerçeğin kuşkuya yer vermeyecek şekilde tespiti bakımından; öncelikle sanığın, katılanı ... Üniversitesine sevk etmiş olmasına yönelik savunmasında ...Üniversitesini meslektaşının orada çalışan eşini aradığını ve bu hastanenin müsait olmadığının tespiti üzerine katılanı ... Üniversitesine sevk ettiğini savunması nedeniyle, öncelikle hasta sevk protokolleri celp edilip incelenerek sanığın bu işleminin usule uygun olup olmadığının araştırılması, ameliyat sonrası gerekli dikkat ve özeni gösterip göstermediğinin bilirkişi aracılığı ile tespit edilmesi; hastanın başka bir hastaneye sevki konusunda genelge ve benzeri bir kural olup olmadığının il sağlık müdürlüğünden sorularak, varsa onaylı bir örneğinin istenmesi; katılanın sevk edildiği ...Üniversitesi Tıp Fakültesi Hastanesi'nde ameliyatını yapan hekimlerin yeniden tanık olarak dinlenmesi ve kendilerinden, hastanın daha erken sevk edilmiş olması durumunda, ayağının kesilmesinin önlenip önlenemeyeceğinin sorulması; sonucuna göre tüm deliller birlikte tartışılarak sanığın hukuki durumunun belirlenmesi gerekirken, eksik araştırma ile beraat hükmü kurulması yasaya aykırı, katılan vekilinin ve Cumhuriyet Savcısının temyiz itirazları bu itibarla yerinde görülmüş olduğundan, hükmün bu sebeplerden dolayı bozulmasına oy birliğiyle karar verildi.

Yargıtay 5. Ceza Dairesi 20.12.2017 tarihli E: 2017/1445, K: 2017/5484 sayılı kararında;

Sanığın ...Hastanesi'nde ortopedi, diğer sanığın ise aynı hastanede dahiliye uzmanı olarak görev yaptıkları, sanıkların hastalara koydukları tanıyla uyumsuz olacak şekilde tıbbi gerekliliği ve yerindeliği olmayan tetkikler istemek suretiyle görevi kötüye kullanma suçunu 
işledikleri iddia olunan olayda; bilirkişi raporunda her iki sanık bakımından, sekreterlerin sehven yaptığı kodlama hatalarına dikkat çekilmekle birlikte, sanığın bir kısım hastaları gereksiz yere MR tetkikine gönderdiği kanaati oluştuğunun bildirilmesi karşısında; ... Teftiş Kurulu'nun ön inceleme raporu ve ekleri de dosyaya eklenip sanıkların hastalara koydukları tanıyla uyumsuz olacak şekilde tıbbi gerekliliği ve yerindeliği olmayan tetkikler isteyip istemediklerine dair savunmalarını da irdeler şekilde konusunda uzman bilirkişi heyetinden denetime imkân verecek nitelikte rapor alındıktan sonra sonucuna göre sanıkların hukuki durumunun tayin ve takdir edilmesi gerektiği gözetilmeden yetersiz bilirkişi raporuna dayanılmak suretiyle ve eksik incelemeyle yazılı şekilde hüküm kurulması yasa gereğince bozulmasına oy birliğiyle karar verildi.

Yargıtay 13. Hukuk Dairesi 05.07.2017 E: 2016/5064 K: 2017/8070 sayılı kararında;

Davacı, bel ağrıları nedeni ile ... Tıp Merkezi'ne başvurduğunu, muayene ve teşhisin davalı doktor tarafından yapılarak bel fitığı teşhisi konulduğunu ve ameliyat olması gerektiğinin bildirildiğini, doktorun el becerisi iyi olan profesör doktoru tavsiye ederek, ameliyatı davalı... Hastanesi'nde bu hocanın yapacağı bilgisini verdiğini, bu duruma güvenerek ameliyat olmayı kabul ettiğini ancak ne ameliyat öncesinde ne de sonrasında profesör doktor ile görüşme imkânının olmadığını, bu nedenle ameliyatı bu doktorun yapmadığından şüphelendiğini, ameliyattan sonra da iyileşmenin olmadığını, önerilen ve uygulanan fizik tedavilerin de işe yaramaması nedeniyle başvurduğu başka bir ortopedi akademisyeninin, kanalın tıkalı olduğunu, ameliyat bölgesinde ameliyat edilmiş bir görünüm izlenmediğini, bu koşullarda fizik tedaviye başlanamayacağını belirttiğini ve ikinci kez ameliyat olmak zorunda kaldığını, yapılan ikinci ameliyattan sonra ağrılarının dindiğini, bu süreçte büyük acı ve ızdırap yaşamış olduğunu ileri sürerek, maddi manevi tazminat isteminde bulunmuştur. Davalılar, davanın reddini dilemişlerdir. Mahkemece, davanın reddine, karar verilmiş; hüküm davacı tarafından temyiz edilmiştir. Mahkemece, dosyaya kazandırılan, Adli Tıp Kurulu 2. ìhtisas Kurulu Başkanlığı'nın raporunda "Semptomatik bel fitığının tedavisinde cerrahinin de bir seçenek olduğu, bel fitığı ameliyatı esnasında fitık tamamen çıkarılamayabileceği gibi yapılan ameliyat sonrasında da bel fitığının tekrarlayabileceği, nüks bel fitığı nedeniyle tekrar ameliyata alınmak zorunda kalınabileceği, çekilen lomber MR ve yapılan muayenesi ile bel fitığı tanısı konulduğu, ameliyata alındığı, sağ L4-5 parsiyel hemilaminektomi yapıldığı, protrude stenotik mesafenin açıldığı ve sinir kökünün serbestleştirildiği, ameliyat sonrası takiplerinde kişinin ağrılarının devam etmesi üzerine lomber MR çekildiği, sonrasında fizik tedavi uygulanmasına karar verildiği ve fizik tedavi uygulandığı, kişinin ağrılarının uygulanan fizik tedaviye rağmen devam etmesi üzerine... Hastanesi'ne başvurduğu, burada nüks bel fitığı tanısı ile ameliyata alındığı, yapılan bu ameliyat sonrasında ağrılarının azaldığı ve nörolojik sekelinin bulunmadığının anlaşıldığı, kişiye konulan tanı ve yapılan ameliyatların tıp biliminin genel kabul görmüş ilke ve kurallarına uygun olduğu, kişide... Hastanesi'nde yapılan bel fitığı ameliyatı sonrası ortaya çıkan tabloların bu tür ameliyatlardan sonra her türlü özene rağmen oluşabilen her hangi bir tıbbi kusur ya da ihmal izafe edilemeyen "komplikasyon” olarak nitelendirildiği, kişinin ameliyatını gerçekleştiren sağlık çalışanlarına atfi kabil kusur tespit edilmediğ’" belirtilmiş; daha sonra alınan ek raporda da, aynı görüş yinelenmiştir. Hükme esas alınan rapor ve ek rapor incelendiğinde, olaya ve tüm iddialara ilişkin yeterli açıklamayı içermediği görülmekle birlikte, mahkemece davacının, profesör doktorun, ameliyatına girmediği iddiasının incelenmediği, bu iddianın karşılanmadığı anlaşılmaktadır. Hal böyle olunca, mahkemece, dava konusuna ilişkin tüm hastane evrakı getirtilmek suretiyle, davacının iddialarının eksiksiz karşılanması, ayrıca üç kişilik bilirkişi kurulundan rapor alınarak, davalıların ayrı ayrı kusurlu olup olmadığının belirlenmesi, sonucuna göre karar verilmesi gerekirken, bu yönler göz ardı edilerek eksik incelemeye dayanılarak yazılı şekilde hüküm kurulmuş olması usul ve yasaya aykırı olup bozmayı gerektirir.

Yargitay 12. Ceza Dairesi 18.05.2017 tarihli E: 2015/14937, K: 2017/4112 sayılı kararında;

Olay tarihinde iki yaşlarında olan çocuk hastanın iki taraflı doğuştan kalça çıkığı tanısı ile ...Hastanesi'ne ailesi tarafından götürüldüğü, anemnezinde altı ay önce iki taraflı doğuştan kalça çıkı ̆̆ tanısı ile kapalı redüksiyonla her iki bacak pelvipedal alçıya alındığının, alçısı açıldığında tedavi sonrası sol kalçasının lukse olduğunun tespit edildiği ve operasyon için "Sol DKÇ (Doğumsal Kalça Çıkığı)" tanısı ile temyize gelmeyen sanık ortopedi uzmanı tarafindan hastaneye yatırıldığı, ameliyat öncesi çocuk hastalıkları ve anestezi uzmanları tarafından konsültasyonların yapıldığı, anestezi uzmanı sanık doktor tarafından görülüp opere olabileceğine karar verildiği, bunun üzerine operasyona alındığı, ameliyatın ortopedi uzmanı tarafindan yapıldığı, anestezi ekibi olarak da ameliyata anestezi uzmanı ve anestezi teknisyenlerinin katıldığı, beyanlara göre hastanın uyutulması ve operasyona başlanmasından sonra anestezi uzmanı sanık doktorun aynı anda başka ameliyatlarda da görevli olması sebebiyle hastanın başından ayrıldığı, ancak anestezi teknisyeni sanığın 
ameliyatın başından sonuna kadar hastanın başında bulunduğu, sanık doktor tarafından ameliyata başlandığında 160 civarında olan nabzın ameliyatın 15. dakikasında 80'e düştüğü, ameliyatta iki kez sevofluran gazı verildiği, ikincisi verildikten sonra hastanın kalbinin durduğu, hastanın kardiak arest olup resüsitasyonla saat 11:00 sularında döndürüldüğü, bu aşamada sanık doktor tarafindan operasyonun durdurulduğu, ancak hastanın geri dönmesi ile ve anestezi uzmanlarının ameliyata devam edilmesi kararı ile sanık tarafından hızlı bir şekilde açık olan yerler kapatılıp ameliyatın sonlandırıldığı, ameliyat sonrası yoğun bakımda takip edilen hastaya şuur bulanıklığı nedeniyle aynı gün ...Tıp Fakültesi Hastanesi'ne sevk edildiği, geldiğinde şuur kapalı olup havalesi bulunan hastaya yapılan tetkikler sonucu hastada beyin hasarı meydana geldiğinin anlaşıldığı ve hastaya ileri derecede mental motor retardasyon, tedavi ile mümkün olmayan kronik nörolojik hastalık ve epilepsi teşhisleri konulduğu, bu aşamadan sonra hastanın iyileşemediği ve kalça çıkığı nedeniyle operasyonlar geçirdiği, olaydan yaklaşık yedi yıl sonra vefat ettiği, Adli Tıp Kurumu 1. İhtisas Kurulu raporuna göre ölümün ameliyat sırasında ortaya çıkan nedeni belirlenemeyen bradikardi ve kardiak arrest sonrası gelişen iskemik hipoksik ensefalopati ve komplikasyonlarından meydana geldiğinin tespit edildiği, henüz ölüm olayı gerçekleşmeden yapılan soruşturma sonucu sanıklar hakkında taksirle yaralama ve sanık hakkında ayrıca ölenin babasından yapmaya mecbur olduğu işi yapmak için para aldığı iddiaları ile rüşvet suçlarından kamu davası açıldığı, burada yapılan yargılama sırasında alınan Yüksek Sağlık Şurası'nın raporunda; sanık ortopedi doktorunun kusursuz, hastaya entübasyon yaptıktan sonra görevi arkadaşına devreden ve olayda sorumluluğu bulunmayan anestezi teknisyeni sanığın kusursuz, hastanın yeterli oksijenle ventilasyonunun sağlanamaması sonucu hipoksi oluşmasına sebep olan anestezi teknisyeninin 1/8 oranında kusurlu, anestezi teknisyenlerinin çalışmalarını yeterince takip etmeyen sanık doktorun 2/8 oranında kusurlu olduklarının belirtildiği, bu dosyada yapılan yargılamada sanıklara taksirle yaralama suçundan mahkûmiyetlerine karar verildiği, hükmün temyizi üzerine dosyanın Yargıtay'a gönderildiği, Yargıtay 5. Ceza Dairesi'nin 07.12.2011 tarihli kararı ile açılan kamu davasının zamanaşımı nedeniyle düşmesine karar verildiği, hastanın 25.06.2009 tarihinde ölmesi üzerine iş bu dosyaya konu sanıkların tamamı hakkında taksirle öldürme suçundan açılan kamu davasının yapılan yargılaması sırasında alınan Yüksek Sağlık Şurası'nın raporunda; “otopsi bulgularına göre, ölümün aspirasyon sonucu gelişen bronkopnomöniye başlı olarak meydana gelmiş olabileceği ve bu duruma daha önce yaşadığı olay neticesinde gelişen nörolojik hasar ve mental retardasyonun sebebiyet vermiş olabileceği, aspirasyon ve bronkopnömoninin pek çok nedenle ortaya çıkabileceği, önceki sekelin ne ölçüde etkilediğinin belirlenemeyeceği, mental retardasyonu olmayanlarda da aynı sürecin gelişebileceği, fark edilmeden gelişebilen pnomönilerde her türlü tedaviye rağmen ölüm oranının yüksek olduğu (\%5-40) göz önüne alındığında; meydana gelen ölümle operasyon sırasında gelişen sekeller arasında illiyet bağı kurulmasının mümkün olamayacağı”" görüşünün belirtildiği anlaşılmakla; dosya kapsamından sanıklara isnat edilen ve daha ağır bir suçu oluşturma ihtimali bulunmayan eylem taksirle öldürme olup, temel sorun suç tarihinin tespiti noktasında toplanmaktadır. Yapılan ameliyat sırasında beyin hasarı meydana gelen hastanın, iyileşmesi gerçekleşmeden ve ameliyatta gelişen iskemik hipoksik ensefalopati, yani beyine yeterli kan ve oksijen gitmemesi nedeni ile yedi yıl sonra ölümü gerçekleşmiştir. Dolayısıyla Kanun'un cezalandırdığı, sanıkların eylemlerini icra ettikleri, yani ameliyatı yaptıkları tarih ile ölüm tarihinin suç tarihi olarak esas alınması ve gerek zaman aşımı gerekse uygulanacak kanun hükümlerinin bu tarih nazara alınarak saptanması gerekir. Bu suretle eylemin icra edildiği yani suç tarihi olan tarih itibariyle sanıklara isnat edilen ve daha ağır bir suç oluşturma ihtimali bulunmayan eylem 765 sayılı TCK'nın 455/1. maddesinde yaptırıma bağlanmış olup, anılan suç aynı kanunun 102/4. maddesi uyarınca beş yıllık zaman aşımına tabidir. Sanıklar müdafilerinin temyiz itirazları bu itibarla yerinde görülmüş olup, hükmün gerçekleşen zamanaşımı nedeniyle bozulmasına oy birliğiyle karar verildi. Söz konusu kararda Yüksek Sağlık Şurası'nın raporu oldukça önemli bilgiler vermektedir.

Yargıtay 13. Hukuk Dairesi 05.04.2017 tarihli E: 2015/15335, K: 2017/4016 sayılı kararında;

Davacı, ayağının kırılması üzerine davalı hastanede davalı doktor tarafından gerçekleştirilen ameliyat ve yaranın takibi sırasında uygulanan tedavi nedeniyle ayağında enfeksiyon olduğunu ve bir türlü iyileşmediğini ileri sürerek, duyduğu üzüntü ve uğradığı zarar nedeniyle maddi ve manevi tazminat talebinde bulunmuştur. Uyuşmazlık, davacının ayağında oluşan enfeksiyon sorununda davalı doktorun herhangi bir kusurunun olup olmadığı noktasında toplanmaktadır. Somut olayda, davacının ayağında meydana gelen kırık nedeniyle davalı hastaneye yatırıldığı ve tedavisinin davalı doktor tarafindan gerçekleştirildiği sabittir. Mahkemece alınan Adli Tıp Kurumu raporunda, düşme sonucu ... Hastanesi'ne getirildiği, çekilen grafilerinde sol tibia $1 / 3$ distal diafiz kırığı ve fibula $1 / 3$ proksimal diafiz kırığı saptandığı, ortopedi uzmanı tarafından plak vida takılarak ameliyat edildiği ve yara takibinin yapıldığı, ameliyat yerinde enfeksiyon geliştiği, kültürde bakteri 
ürediği, tedaviye rağmen yaranın kapanmadığı, daha sonra ...Hastanesi'nde flep yapılarak tedavi edildiği, her ne kadar dosyadaki hastane evrakında yapılan işleme ait hasta onamına rastlanmamış olsa da tüm ortopedik operasyonlarda en sık komplikasyon enfeksiyon olarak kabul edildiğinden, doktora atfi kabil kusur bulunmadığı belirtilmiştir. Mahkemece bu rapora itibar edilerek hüküm kurulmuş ise de rapor hükme elverişli değildir. Anılan rapor, yaranın açık kalması durumunda ortaya çıkacak sonuçlar ve yaranın takibine ilişkin olarak davalı doktorun sorumluluğu noktasında yeterli bir açıklama içermediğinden, olayda davalıların kusurlu olup olmadığının tespitinde yeterli değildir. O halde mahkemece üç kişilik bilirkişi kurulundan, davacının itirazları da karşılanmak suretiyle olayda yapılan ameliyat ile sonrasında davacının ayağında meydana gelen enfeksiyonun takibi sırasında herhangi bir hata, ihmal olup olmadığı konusunda, nedenleri açıklayıcı, rapor alınarak sonucuna göre karar verilmelidir. Mahkemece bu yönler göz ardı edilerek eksik inceleme ile yazılı şekilde hüküm kurulmuş olması usul ve yasaya aykırı olup bozmayı gerektirir.

\section{* * *}

Yargıtay 12. Ceza Dairesi 17.10.2016 tarihli E: 2015/14353, K: 2016/11954 sayılı kararında;

Yere düşerek sol kol dirsek kemiğinde parçalı kırık meydana gelen hastanın... Hastanesi'ne götürüldüğü, hastane görevlileri tarafindan gerekli tetkikler yapılarak kırığın damar sinir yaralanması yapabilecek nitelikte olması nedeniyle acil opere edilmesi gerektiğinden bahisle ameliyat edilmesine karar verildiği, sanığın anestezi uzmanı doktor olarak ameliyatta yer aldığı, ameliyattan sonra ilgili servisine götürülen hastada aynı gün saat 21:45 sıralarında kardiyopulmoner arrest gelişmesi üzerine görevliler tarafından gerekli tıbbi müdahalelerin yapıldığı, hastanın yoğun bakım servisine yatırılarak solunum cihazına bağlandığı ve takibinin sürdürüldüğü ancak gece saat 03:00 sıralarında tekrar fenalaşan hastanın, solunum ve kalp atımlarının durduğu, hastaya görevliler tarafından yoğun bakımda kalp masajı ile canlandırma işlemleri yapıldığı fakat bu işlemlerden olumlu yanıt alınamadığı ve hastanın hayatını kaybettiği olayda Adli Tıp Kurumu Genel Kurulu tarafından düzenlenen raporda "Otopsi ve klinik bulgular birlikte değerlendirildiğinde küçüğün ölümünün kendinde mevcut akciğer hastalığının (pnömoni) humerus kırığı nedeniyle uygulanan anestezi ve ameliyatın yükü sonucu ortaya çıkan oksijensizlik ve gelişen komplikasyonlardan ileri geldiğinin kabulü gerektiği, dosyada preoperatif anestezi vizit fişi olmamakla birlikte anestezi uzmanının hastaya ameliyat öncesi gördüğünü belirttiği ve dosyadan hastaya ait tetkikler incelendiğinde ameliyat öncesi hastaya yaptırılan laboratuar tetkiklerinin yeterli ve normal olduğu, anestezi fişi incelendiğinde hastaya anestezi sırasında kullanılan ilaçların doz ve niteliklerinin uygun olduğu, çocukta tespit edilen kırığın damar sinir yaralanması yapabilecek, acil opere edilmesi gereken bir kırık olduğu, akciğerde bronkopnömoni tespit edilmiş olup, bu bronkopnömoninin en az bir haftalık olduğunun anlaşıldığı dikkate alındığında, küçükte ameliyat öncesinde bronkopnömoninin mevcut olduğu, anestezi uzmanı tarafından değerlendirme sırasında fark edilmemiş olduğu, bu durumun bir eksiklik olduğu ancak çocukta tespit edilen humerus kırığının acilen ameliyat edilmesi gerektiğinden tanı konulmuş olması durumunda da ameliyatın acil yapılmasının zorunlu olduğu, ölüm meydana gelmesinden dolayı anestezi, ortopedi uzmanına kusur atfedilemeyeceği oy birliği ile mütalaa olunur." şeklinde görüş içeren rapora itibarla, atılı suçtan kusuru bulunmayan sanık hakkında beraat kararı verilmesine dair yerel mahkemenin kabulünde bir isabetsizlik görülmemiştir.

Yargitay 12. Ceza Dairesi 21.06.2016 tarihli E: 2016/3825, K: 2016/10579 sayılı kararında;

... Hastanesi'nin muayene raporu ve reçetesinde; üç gün önce kolunun üzerine birisinin düşmüş olduğu ifadesiyle geldiği, sol dirsek eklem içi kırı̆̆ı teşhis edildiği, genel durumunun iyi, sol dirsek palpasyonu ağrılı, dirsek hareketleri ağrılı, el ve ön kolda yumuşak dokuda ödem olduğu, dolaşım problemi olmadı̆̆ı, sinir problemi olmadığı, el parmaklarına ve el bileğine hareket yaptırılabildiği, grafisinde sol dirsek eklem içi kırı̆̆ı (nondeplase) saptandığı, dirsek üstü alçı atel yapıldığı, medikal tedavi başlandığı, ağrı kesici ve ödem geriletici, elevasyon ve takibe alındığı, kontrolde BT çekilip sonucuna göre tedavisinin devamına karar verileceği, Apranax ${ }^{\circledR}$ tb $2 \times 1$, Minoset ${ }^{\circledR}$ tb $2 \times 1$ reçete edildiği, şeklinde belirtildiği, her ne kadar dosya içerisinde herhangi bir hastane evrakı mevcut olmasa da taraf ifadelerine göre çocuğun ağrısının artması, sırt ve karın ağrısı olması üzerine tekrar aynı hastaneye götürdükleri, doktorun alçısını kısalttığını eve gönderildiğini, şikâyetleri devam eden ve mide bulantıları başlayan çocuğun hastaneye götürüldüğü, Apranax® isimli ilacı keserek diğer ilaçlarını içmesi önerilerek eve gönderildiği, akşam sırtının acıdığını ve karnının ağrıdığını söylemesi üzerine hastaneye götürmek istediklerini ancak çocuğun gitmek istemediğini, daha sonra fenalaşması üzerine... . Hastanesi'ne götürdüklerini, nöbetçi doktor olmadığı söylenerek hastaneye kabul edilmediklerini, bunun üzerine başka hastaneye gittiklerini, buradaki geçici raporunda; üç gün önce düşmüş olduğu, sol kolda çatlak olduğu ve alçıya alınmış olduğu, önceki akşam terleme ve üşümeleri olduğu, sabah kalktıklarında 
kusmuş ve baygın halde buldukları, bilincinin kapalı, oryantasyon ve kooperasyonun olmadığı, IR(Işık refleksi)-/-, pupilleri fix dilate olduğu, ağrılı uyaranlara cevap vermediği, patolojik refleksin olmadığı, tansiyon ve nabız alınamadığı, solunumu olmadığı, ex duhul olarak geldiği, 30 dakika kardiopulmoner resüsitasyon uygulandığı, ancak solunum ve kalp tepe atımının geri dönmediği, 07:45'te ex kabul edildiği, ölüm nedeninin anlaşılamadığı, şeklinde belirtildiği, Adli Tıp Kurumu Morg İhtisas Dairesi'nin otopsi raporunda "Sol radius kemiğinde kırık ve kırık çevresinde yoğun iltihap görülen kişinin ölümünün nekrozlaşan taze lobüler pnömoni, irinli fibrinli plörite bağlı solunum yetmezliği sonucu meydana gelmiş olduğunun" belirtildiği, Adli Tıp Kurumu 1. İhtisas Kurulu'nun mütalaasında tıbbi belgeler ve otopsi raporuna göre; çocuğun ölümünün künt travmaya bağlı yumuşak doku zedelenmesi ile bu bölgede oluşan enfeksiyona bağlı komplikasyonlar sonucu meydana gelmiş olduğunun" belirtildiği, Adli Tıp Kurumu 3. İhtisas Kurulu'nun mütalaasında " doktor tarafından ilk görüldüğü gün kırığa yapılan tedavinin uygun olduğu, ancak otopsisindeki bulguların yaygın enfeksiyon göstergesi olduğu, ölümden bir gün önce muayene eden aynı hekimin mevcut bulguları tespit edememiş olmasının eksik bir eylem olduğu, yeterli takip ve tedavi yapmamış olması nedeniyle doktorun eyleminin tıp kurallarına uygun olmadığının" belirtildiği, Yüksek Sağlık Şurası'nın raporunda "Dosyadaki bilgi, belge ve bulgular değerlendirildiğinde; hastanın doktor tarafından ilk görüldüğü gün kırığa yapılan tedavinin uygun olduğu, ancak ölümünden bir gün önce karın ve sırt ağrısı olan hastayı muayene eden doktorun hastada sepsise yol açacak pnömoni bulgularını tespit edememiş olmasının eksiklik olduğu, ölüm sebebinin sepsis olduğu, yeterli takip ve tedavi yapmamış olmasından dolayı doktorun özen ve dikkat eksikliğinin olduğuna, bilinçli taksirinin ise söz konusu olmadığına şuramızca oy birliği ile karar verildiği, şeklinde belirtildiği, Adli Tıp Kurumu 1. İhtisas Kurulu'nun mütalaasında "çocuğun başvuru şikâyetlerine göre konulan tanının ve yapılan tedavinin uygun olduğu, karın ve sırt ağrısı şikâyetleri ile getirildiğinde herhangi bir muayene ve tetkik yapılmadan veya çocuk hastalıkları konsültasyonu istemeden şikâyetlerini Apranax® adlı ilaca bağlamış olması nedeniyle doktorun kusurlu olduğu, doktorun karın ve sırt ağrısı şikâyetlerinin ilaca bağlanmış olması nedeniyle kusurlu olmakla birlikte hasta yakınının çocukta öksürük, ateş, solunum sıkıntısı gibi yakınmalarının bulunduğuna dair anamnez vermemiş olması ve muayeneden bir gün sonra ölmüş olması nedeniyle ölümünün tek başına hekim kusuru nedeniyle meydana geldiğinin söylenemeyeceği, doktorun kusurunun ölüm meydana gelmesindeki etkisi $8 / 8$ üzerinde değerlendirildiğinde $2 / 8$ olarak kabulünün uygun bulunduğu, kusurlu eylem sorulduğu üzere bilinçli taksir olarak değerlendirilemeyeceğinin" mütalaa edildiği ve son olarak bozma ilamına uyularak yapılan yargılama sırasında alınan Adli Tıp Grup Başkanlığı Genel Kurul kararında da başvuru şikâyetlerine göre konulan tanının ve yapılan tedavinin uygun olduğu, karın ve sırt ağrısı şikâyetleri ile getirildiğinde herhangi bir muayene ve tetkik yapılmadan veya çocuk hastalıkları konsültasyonu istemeden şikâyetlerini Apranax ${ }^{\circledR}$ adlı ilaca bağlamış olması nedeniyle doktorun kusurlu olduğu, karın ve sırt ağrısı şikâyetlerinin ilaca bağlanmış olması nedeniyle kusurlu olmakla birlikte hasta yakınının çocukta öksürük, ateş, solunum sıkıntısı gibi yakınmalarının bulunduğuna dair anamnez vermemiş olması ve çocuğun muayeneden bir gün sonra ölmüş olması nedeniyle ölümünün tek başına hekim kusuru nedeniyle meydana geldiğinin söylenemeyeceği oy birliği ile mütalaa olunur" şeklinde rapor verildiği ve sanığın kusurlu olduğu anlaşılmakla; incelenen dosya kapsamına göre, sanık müdafiinin eksik inceleme ile hüküm verildiğine ve kusura, katılanlar vekilinin ise eylemin bilinçli taksirle işlendiğine ve adli para cezasının az takdir edildiğine ilişkin temyiz itirazlarının reddiyle, hükmün isteme uygun olarak onanmasına oy birliği ile karar verildi.

* * *

Yargıtay 12. Ceza Dairesi 31.05.2016 tarihli E: 2016/2176, K: 2016/9149 sayılı kararını muhalefet şerhi önem arz ettiği için burada yer vermek doğru olacaktır. "Taksirle yaralama suçundan sanığın mahkûmiyetine ilişkin hüküm eksik kovuşturmaya dayalı olarak verildiğini düşündüğümüzden sayın çoğunluğun onama yönündeki görüşlerine katılmıyoruz. Şöyle ki: düşme nedeniyle ... Hastanesi Acil Servis polikliniğine getirilen hastanın yapılan muayene ve tetkiklerinde femur boyun kırığı tespit edildiği, opere edilerek bipolar protez yerleştirildiği, anestezi önerisiyle takip amaçlı cerrahi yoğun bakıma alındığı ve izlenimde ek problem olmayan hastanın taburcu edildiği, sol kalçada ağrı ve üzerine basamama şikâyetleri devam eden hastanın, ilk ameliyattan yaklaşık 2 yıl sonra tarihinde ... Hastanesi'ne müracaat ederek burada ortopedi uzmanı olan sanık tarafından yapılan muayenede iç dış rotasyonları ağrılı olması protez gevşemesi olarak değerlendirildiği, yapılan kan tahlilleri ve çektirilen kemik sintigrafisi neticesi gevşemenin enfeksiyondan kaynaklanmadığı önceki ameliyat tekniğinden kaynaklandığı sonucuna varılarak, gerekli pelvis grafisi ve serolojik tetkikler ile kardiyoloji konsültasyonunun yapılmasının ardından epidural anestezi ile sanık tarafindan revizyon total kalça protezi ameliyatına alındığı, salah halinde bir hafta sonra kontrol önerisi ile taburcu edildiği, sol kalçada ağrı şikâyetinin devamı üzerine sanık tarafından hasta tekrar görülerek yapılan tetkiklerin ardından 
kalça femoral sitemin distale migre olduğunun tespiti ile tekrar ameliyat edildiği, bu operasyonda distal femoral sitemin çıkartıldığı, çimentolu olarak yerleştirildiği, taburcu edildikten iki gün sonra sol kalçada ağrı ve yürüyememe şikâyeti ile hasta ... Hastanesi'ne yatırılarak burada yapılan tetkiklerin ardından geniş femoral kemik destekli uzun stemli revizyon protez ameliyatının yapıldığı ve taburcu edildiği, Adli Tıp Kurumu 3. İhtisas Kurulu'nca düzenlenen raporda sanık tarafindan yapılan 2. operasyon sırasında periprostetik kırık oluştuğu, bu durumun ameliyat sırasında meydana gelebilecek bir komplikasyon olduğu, önlem alınması gerektiği, hekim tarafindan fark edilip edilmediğinin kayıtlarda bulunmadığı, fark edildiyse ne tür bir önlem alındı̆̆ının kayıtlı olmadığı cihetle sanık tarafından yapılan eylemin tıp kurallarına uygun olmadığı ifade edilmiş ise de, sanık savunmasında operasyon sonrası çekilen grafilerde kırığı tespit ettiğini ve bu hususta hasta ve yakınlarına bilgi verdiğini, hasta yakınlarının da önlem almasına müsaade etmeden onların zorlaması ile hastanın başka bir hastaneye sevkini sağladığını ileri sürdüğü ve bu savunmanın ölenin oğlu tanık tarafından da kısmen doğrulandığı da nazara alınarak gerekli araştırmanın yapılıp ardından dosyanın Adli Tıp Kurumu Genel Kurulu'na gönderilerek, sonucuna göre hukuki durumunun tayin ve takdiri gerekir. Açıkladığımız bu gerekçelerden dolayı hükmün eksik inceleme ile verildiğini düşündügüumüzden bozulması gerekirdi. Bu nedenlerden dolayı sayın çoğunluğun mahkûmiyet hükmünü onama yönündeki görüşlerine katılmıyoruz.

\section{* * *}

Yargıtay 13. Hukuk Dairesi 04.04.2016 tarihli E: 2015/11423, K: 2016/9370 sayılı bir başka kararında davacı, hamileyken yere düştüğünü, sol kolunun bilek ve dirsekten kırıldığını, davalı şirkete ait ... Hastanesi'ne kaldırıldığını, davalı doktorun önerisiyle ameliyat olduğunu, ameliyattan sonra iyileşmeyince aynı doktora müracaat ettiğinde kolunun matkapla dirsek ve bilekten delinerek tavana asılması gerektiğini söylediğini, hamileliği nazara alınarak bu işlemin uyuşturulmadan gerçekleştirildiğini, 2. müdahale esnasında dayanılmaz acılar çektiğini, kırıkların yine iyileşmemesi ve kolundaki yaradan ağır bir koku ve akıntı gelmesi üzerine davalı doktor tarafından 3. kez ameliyat edildiğini, kırıklar yine iyileşmeyince ... Üniversitesi Hastanesi'ne müracaat ederek oradaki ortopedi doktoru tarafindan yapılan ameliyatların tamamen yanlış olduğu ve kolunun düzelme ihtimalinin neredeyse bulunmadığının söylenerek son çare olarak ... Hastanesi'nde bir doktora gönderdiğini, o doktorun da kolun düzelme ihtimalinin çok düşük olduğunu, bir çare olarak ameliyat olabileceğini söylediğini, ameliyatı müteakip iltihabın steril olmayan hastane odasındaki matkapla delme sırasında oluşabileceğini beyan ettiğini, kolun iyileşmesi için bir başka doktor tarafından da ameliyat edildiğini, hatalı ve özensiz tıbbi müdahaleler sonucu sakat kaldığını, ruh sağlığının aşııı derecede bozulduğunu ileri sürerek, fazlaya ilişkin hakları saklı kalmak kaydıyla ameliyat, ilaç, ulaşım, iş ve kazançtan yoksun kalma zararlarının tazmini için 10,000,00 TL maddi, 15,000,00 TL manevi tazminatın işleyecek yasal faizi ile birlikte davalılardan müştereken ve müteselsilen tahsiline karar verilmesini istemiş, ıslahla maddi tazminat talebini 167,621,22 TL'ye yükseltmiştir. Davalı doktor ve davalı şirket, davanın reddini dilemişlerdir. Mahkemece, davalı doktor hakkında açılan ceza dava dosyası esas alınmak suretiyle, ceza dosyasında alınan Yüksek Sağık Şurası raporunda özensiz ve yetersiz yaklaşımından dolayı davalı doktorun $4 / 8$ oranında kusurlu olduğu, mahkemece alınan Adli Tıp 3. İhtisas Kurulu raporuna göre de davacının yüksekten düşme olayına bağlı humerus suprakondiler kırığı nedeniyle \%50 oranında meslekten kazanma gücünden kaybetmiş sayılacağının belirlendiği, bu miktarın 83,684,61 TL'sinin davalılardan ayrı ayrı tahsiline karar verilmiş; hüküm, taraflarca temyiz edilmiştir. Davalı doktor vekili tarafından dilekçe ile davaI doktorun vefat ettiği, yasal mirasçılarının da mirası reddettiğine dair İzmir 4. Sulh Hukuk Mahkemesi'nin 2015/1347 Esas, 2015/1335 Karar sayılı mirasın reddi kararının dosyaya sunulduğu anlaşılmaktadır. Hal böyle olunca; mahkemece, davalı doktorun veraset ilamı ile mirasın reddi kararının incelenip, taraf teşkili sağlanarak sonucuna göre bir karar verilmek üzere, hükmün bozulmasına karar vermek gerekmiştir.

Yargitay 12. Ceza Dairesi 17.03.2016 tarihli E: 2015/14783 K: 2016/4357 sayılı kararında;

Adli Tıp Genel Kurulu'nun raporunun sonuç bölümünde konjenital kifoz nedeniyle üç kez ... Ortopedi ve Travmatoloji bölümünde opere edildiği, son operasyonda kullanılan vidaların uçlarının ciltten çıkması üzerine ...Ortopedi ve Travmatoloji bölümüne yatırıldığı, gerekli hazırlıkları takiben ameliyata alındığı, ancak işlem tamamlanmak üzere iken cilt dikişlerine geçildiği sırada aniden kardiyak arrest geliştiği, hemen resüsitasyona başlandığı, yaklaşık bir saat resüsite edildikten sonra kalbinin çalışmaya başladığı, ancak olay sırasında gelişen hipoksiye bağı olarak nörolojik problemler ile yaklaşık üç ay sonra bu haliyle taburcu edildiği anlaşılan hasta hakkında düzenlenmiş adli ve tıbbi belgelerin incelenmesi sonucunda kardiyak arrest nedeni kesin olarak bilinememekle beraber yüzükoyun pozisyonunda yapılan skolyoz cerrahisinde sırtta bulunan ve cerrahi için açılan bölgedeki venlerden hava embolisinin oluşabileceği, bu nedenle de kardiyak arrest gelişebileceği, bu tür vakaların literatürde bulunduğu, 
hastanın ameliyat öncesi dekstrokardisi bulunduğunun kayıtlı olduğu, anestezi ekibinin çabasıyla kalbin yeniden atmasının sağlandığı ve hastanın yaşama döndürüldüğü, her hastada kalbin niye durduğunun bilinemeyebileceği, çünkü saptanamayacak ve öngörülemeyecek nedenlerle de kalbin ani olarak durabileceğinin tıbben bilindiği, ameliyat sırasında yapılan işlemlerin tıp kurallarına uygun olduğunun mütalaa edildiği anlaşılmakla, yapılan yargılama sonunda, yüklenen suç açısından faillerin kusurunun bulunmadığı gerekçesi gösterilerek mahkemece kabul ve takdir kılınmış olduğundan, katılan vekilinin sanıkların kusurlu olduğuna, eksik inceleme ile beraat kararı verildiğine ilişkin temyiz itirazlarının reddine oy birliği ile karar verildi.

Yargıtay 12. Ceza Dairesi 08.03.2016 tarihli E: 2015/4088, K: 2016/3539 sayılı kararında;

Ağırlık düşmesi sonrası burun ve sol diz yaralanması yaşayan mağdurun sol fibula ve tibia kemik kırıklarının hayat fonksiyonlarını 3. derecede etkileyecek şekilde yaralandığı, kaldırıldığı hastanede yapılan ameliyat ve alçı uygulamasından sonra salah bularak taburcu edildiği, evinde istirahat halinde ve sıkıntısız şekilde iyileşme süreci devam ederken taburcu olduktan 18 gün sonra bacağındaki ağrı ve nefes almakta zorlanma şeklinde gelişen şikâyetleri ile ani biçimde fenalaşması sonucu ölümü ile sonuçlanan olayla ilgili Adli Tıp Kurumu tarafindan düzenlenen raporda ölüm nedeninin kesin olarak tespitine imkân bulunmadığı, bununla birlikte ölüm belgesinde yazılı bulunan ölüm nedeni (emboli ve tromboz) doğru olarak kabul edildiği takdirde; bu tablonun ekstremite kırıklarını müteakip immobilizasyona bağlı olarak meydana gelmesinin tıbben mümkün olduğunun kabulü gerektiğinin ifade edildiği; Adli Tıp Kurumu 1. İhtisas Kurulu'nun talebi doğrultusunda ölenin sol tibia ve fibula kemikleri 04.07.2012 tarihli fethi kabir işlemi suretiyle incelenmek üzere Adli Tıp Kurumu Morg ihtisas Dairesi'ne gönderilerek burada sol tibianın alt $1 / 3$ hizasında oblik seyirli, ayrıIı kırık vaziyette olduğu ve bu kırık hatlarında yer yer iyileşmeye bağı kaynama noktalarının mevcut olduğu, bunun dışında tibiada bir adet medüller çivi ile iki adet proksimalde ve iki adet distalde olmak üzere toplam dört adet plak vidanın mevcut olduğu, fibulanın ise alt $1 / 3$ hizasında kelebek seklinde üç parçaya ayrılacak vaziyette kırılmış olduğunun tespit edildiği, Morg intisas Dairesi'nin yaptığı bu makroskobik incelemenin ardından Adli Tıp Kurumu 1. İhtisas Kurulu tarafindan düzenlenen 26.09.2012 tarihli raporda; zamanında otopsi yapılarak iç organ değişimleri araştırılmamış olmakla birlikte tıbbi belgelerinde iş kazası sonucu yaralanma ile ölümü arasında illiyet bağı bulunduğunun ifade edildiği, Adli Tıp Kurumu 1. İhtisas Kurulu'nca düzenlenen raporda kişinin ölümünün genel beden travmasına bağlı tibia ve fibula kırıkları ile birlikte gelişen komplikasyonlar sonucu meydana gelmiş olduğunun kabulü gerektiği, muayene takip ve tedavisine katılan ilgili hekimlerin atfı kabil kusuru bulunmadığı, ölene ameliyat sonrası atel ve sonrasında alçı yapıldığı ve antikoagülan tedavi verilmediğinin hastane kayıtlarında görüldügüüün ifade edildiğinin anlaşılması karşısında; mezar açılma sonrası kalp ve akciğer üzerinde inceleme yapılmadığı hususları ve taburcu işlemi sonrası reçete edilen ilaçlarda dikkate alınarak ve Adli Tıp Kurumu 1. Ihtisas Kurulu'nun illiyet bağına ilişkin raporlarını düzenleyen heyetler arasında Ortopedi ve Travmatoloji uzmanı ile kalp damar cerrahisi ve göğüs hastalıkları uzmanlarına yer verilmemesi ve bilimsel mütalaalarda ileri sürülen hususlarla bu raporlar arasındaki çelişkilerin giderilip olay ile ölüm arasında illiyet bağının, bulunup bulunmadığı ve ölüm nedeninin duraksamaya yer vermeyecek şekilde tespiti bakımından bir de Adli Tıp Kurumu Genel Kurulu'ndan rapor alınarak sonucuna göre sanıkların hukuki durumunun takdir ve tayini gerekirken, eksik incelemeyle yazılı şekilde sanıkların mahkûmiyetlerine karar verilmesi, kanuna aykırı olup hükmün bozulmasına oybirliğiyle karar verildi.

* $\quad * \quad *$

Yargitay 12. Ceza Dairesi 04.06.2015 tarihli E: 2014/21000, K: 2015/9863 numaralı kararı... Hastanesi'nde Ortopedi ve Travmatoloji uzmanı olarak çalışan sanık doktorun, olay günü sol kolu üzerine odun yığının devrilmesi neticesinde, hastanenin acil polikliniğine başvuran katılanı muayene ettiği, çekilen iki yönlü röntgen filminde, hastada sol kol dirsek çııığı, eklem bütünlüğünün bozulduğu, ekleme komşu yumuşak dokularda kalınlık artışının mevcut olduğunun tespit edildiği ve hastanın kolunun alçı ateline alındığı, bir gün sonra taburcu edildiği ve iki hafta sonra kontrole gelmesinin sanık doktor tarafından söylendiği, hastanın şiddetli ağrı şikâyeti ile bir hafta sonra tekrar sanık doktora gittiği ve doktorun ağrı kesici verip gönderdiği, hastanın iki hafta sonra tekrar geldiğinde, sol kolda kararma ve su toplamasının tespit edildiği, koldaki su boşaltıldıktan sonra plastik cerrahiye sevk edildiği, ameliyat olması gerektiği söylendiği, bu süreç içinde hastanın kendi isteği ile... Tıp Fakültesi tarafından takip edildiği, kalp hastası olması nedeni ile ameliyat edilemediği, tedavilerinin kalp damar cerrahisi ve plastik cerrahi tarafından birlikte yürütüldügü, sol kol serçe parmağının damar ve sinirlerdeki ezilme nedeni ile ampute edildiği, sol el parmaklarındaki his kaybı ve \%40 doku kaybının, hasta katılanda sol kol işlev kaybına, duyulardan ve organlardan birinin işlevinin yitirilmesine neden olduğu olayda Yüksek Sağılı 
Şurası'nın oybirliği ile verdiği “...dirsek çıkığı tanısıyla gelen hastayı damar yaralanmasını göz önüne alarak radial ve ulnar damar muayenesi yapmadığı ve hastayı eksik değerlendirdiği ve buna bağı olarak hastanın kolundaki arızaya sebebiyet verdiği " şeklindeki raporu ve Adli Tıp ihtisas Kurulu'nun oybirliği ile verdiği “... dirsekten el bileğine uzanan doku kaybı ulnar arterde tam kayıp radial arterin kollateral damarlarla beslendiği, volkman iskemik kontraktürü teşhisi konulduğu belirlenmiş olup bu tip bir yaralanma ile gelen hastada bölge damarları açısından yaralanma olup olmadığı yönünden çok dikkatli muayene ve klinik gözlem yapılması gerektiği, ayrıca alçı atel uygulanması sonrası oluşabilecek komplikasyonlar yönünden de hastanın aydınlatılması ve ortaya çıkan klinik şikâyetlerde her türlü ihtimalin göz önüne alınmasının tıbbi bir gereklilik olduğu, olayda ise aynı hal ve şartlarda bir Ortopedi ve Travmatoloji uzmanından beklenen özenin gösterilmediği, teşhisteki gecikme nedeniyle kişide yaygın doku kaybı ile karakterize klinik tablonun ortaya çıktığı ve adı geçen doktorun kusurlu olduğu" yönündeki raporların, dosya oluş ve kapsamına uygun olduğu ve söz konusu raporların hükme esas alınmasında bir isabetsizlik bulunmadığı anlaşılmakla; sanığın müdafiinin kusura iliş̧kin temyiz itirazlarının reddiyle, hükmün isteme uygun olarak onanmasına oy birliğiyle karar verildi.

Yazıda yer verilen kararlarda da görüldüğü gibi birçok dava eksik inceleme sonucu tekrar yerel mahkemeye gönderilmiş, kısmen veya tamamen bozulmuştur. Mevcut bu durum davaların sonuçlanma süresini uzatmakla birlikte gerek davacılar gerek davalılar açısından oldukça yıpratıcı olmaktadır. Hekimlerin yaptıkları her uygulamaları kayıt altına almaları ve bu kayıtların dava aşamasında sunulması pek tabidir ki bu sürelerin kısalmasına neden olacaktır. Bununla birlikte oluşan uyuşmazlıkların taraflar açısından daha iyi değerlendirilmesinden ve gerekli ön hazırlıkların yapılmasından sonra dava sürecine girilmesi daha efektif bir sistemin oluşmasına zemin hazırlayacaktır.

\section{KAYNAKLAR}

* Iilgili yazıda bulunan yüksek mahkeme kararları mevzuat bilgi bankalarından alınmıştır. 